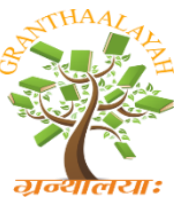

$$
\begin{gathered}
\text { INTERNATIONAL JOURNAL OF RESEARCH } \\
\text { GRANTHAALAYAH } \\
\text { A knowledge Repository }
\end{gathered}
$$

Science

\title{
SILICOSIS, A MONUMENTAL OCCUPATIONAL HEALTH CRISIS IN RAJASTHAN-AN EPIDEMIOLOGICAL SURVEY
}

\author{
Mohammad Shamim *1, Dr Waheeb D.M. Alharbi ${ }^{2}$, Dr Tariq Sultan Pasha ${ }^{3}$, Dr Mohamed \\ Osama Mustafa Nour ${ }^{4}$ \\ ${ }^{* 1}$ Research Scholar, Department of Health and Biomedical Sciences, Symbiosis International \\ University, Pune-India \\ ${ }^{* 1}$ Lecturer, Faculty of Public Health \& Health Informatics, Umm Al Qura (UQU), Makkah, KSA \\ ${ }^{2}$ Dean, Faculty of Public Health \& Health Informatics, Umm Al Qura (UQU), Makkah, KSA \\ ${ }^{3}$ HoD, Department of Occupational Health, Faculty of Public Health \& Health Informatics, \\ Umm Al Qura (UQU), Makkah, KSA \\ ${ }^{4}$ HoD, Department of Health Education and Health Promotion, Faculty of Public Health \& \\ Health Informatics, Umm Al Qura (UQU), Makkah, KSA
}

\begin{abstract}
An epidemiological survey was carried out to assess the magnitude of silicosis in Karauli, a district located in the eastern part of Rajasthan. Silicosis, an occupational disease, which is caused by inhalation of the silica dust; marked by inflammation and scaring of the lungs resulting in nodular lesions in the upper lobes of the lungs. It is a fatal fibrotic pulmonary disease, which is irreversible in nature. Silicosis burden is substantial globally. In India, epidemiological surveys conducted time-to-time show that the problem is more severe in unorganized sector. Silicosis has emerged at epidemic level in Rajasthan due to exponential growth in the mining sector, inadequate Governmental policies, and poor implementation of the laws of the land. A study in 1992-94 carried out by the DMRC, Jodhpur reported that 9.9\% sandstone workers have silicosis. A study conducted by the NIMH in Karauli (2013) revealed that $74 \%$ of them were suffering from the silicosis. However, all these surveys were conducted with the high-risk groups hence they are population measures. This survey intended to assess the magnitude of silicosis amongst the general population in the Karauli, one of the most backward districts of Rajasthan. A village (with approximately 1000 population) was considered as sample unit. Total 6 villages from the 4 regions of the district with a population of 6975 were covered in this cross sectional survey. All the adult population having respiratory symptoms and known history of mining were included in the study. Two questionnaires were used, one to gather occupational and medical history and the SGRPQ to assess the Health Related Quality of Life (HRQoL). The SGPRQ is a self-administered questionnaire, which produces activity, symptoms, and impact scores. Data were analyzed using SPSS software and Excel based analysis tool of SGPRQ. Results revealed that 2758 cases have been diagnosed with silicosis and 2267 cases with disease had received compensation from the Government till February 2017 in Karauli district. The Karauli block of the district had highest number of confirmed silicosis cases followed by Mandaryal, and Hindaun blocks of the district. The SC community is the worst
\end{abstract}


affected (77\%) followed by the ST (13\%), OBCs (9\%), and General community (<1\%); $39 \%$ subjects had silicosis whereas $61 \%$ subjects had severe to mild respiratory difficulties with known history of sandstone mining activities and were categorized as suspected cases of silicosis. No women and no minors were found to have silicosis. The prevalence of the silicosis in all the 6 villages differed; overall prevalence was $12 \%$ (4\% confirmed and $8 \%$ suspected cases). However, the prevalence of confirmed cases amongst the male (6+ years) was $10 \%$. Variables exposure to silica dust is significantly correlated $(\mathrm{p}=0.01)$ with the smoking, the symptom, activity, impact, and total scores; implying that the higher the exposure to silica dust more the chances of developing the disease or severity of the symptoms and impact of the disease on quality of life.

Keywords: DMRC: Desert Medicines Research Center; Jodhpur; NIMH: National Institute of Miners' Health Nagpur; COPD: Chronic Obstructive Pulmonary Diseases; PMB: Pneumoconiosis Medical Boards; OSHA: Occupational Safety and Health Administration; QoL: Quality of Life.

Cite This Article: Mohammad Shamim, Dr Waheeb D.M. Alharbi, Dr Tariq Sultan Pasha, and Dr Mohamed Osama Mustafa Nour. (2017). "SILICOSIS, A MONUMENTAL OCCUPATIONAL HEALTH CRISIS IN RAJASTHAN-AN EPIDEMIOLOGICAL SURVEY." International Journal of Research - Granthaalayah, 5(7), 554-583. https://doi.org/10.29121/granthaalayah.v5.i7.2017.2164.

\section{Introduction}

An Italian named Bernadino Ramazzini in 1705 first identified silicosis (Sil-i-koh-sis) disease. He is considered as founder of occupational/industrial medicine (MIA, 2008). Its full name is 45 English letter words "Pneumonoultramicroscopicsilicovolcanokoniosis", the longest words in English language. This disease is usually mistaken for Tuberculosis. Crystalline silica, asbestos, soft coal, metal dust, jute or hemp dust, dust of animal or vegetable origin and other materials have fibrogenic effect on lungs. The name of the disease changes according to the kinds of dust the person is exposed to. Workers exposed to iron dust suffer from "Siderosis"; workers exposed to coal dust suffer from "Pneumoconiosis" and workers exposed to organic dust such as cotton, jute or hemp dust suffers from "Byssinosis". The dust from animals or vegetables origin, which may include flour, pollen, animal hair, feathers, molds, fungus, and insects, may cause Bronchial asthma or "aleveolitis.

Silicosis is caused by inhalation of the silica dust; it is marked by inflammation and scaring of the lungs resulting in nodular lesions in the upper lobes of the lungs (WHO, 2007). It's a fatal fibrotic pulmonary disease, which is irreversible in nature (Greenberg et al., 2007). Historically disease associated with exposure to silica has been described in many ways. Hippocrates named it, condition of "breathlessness". Lohneiss in 1690 described it as "Lung disease" due to exposure to stone dust. Benardo Ramazzini called it "miners' phthisis", Other people called it mason's disease, grinders asthma, potters' rot, and stone cutter disease. In 1870, Peacock and Greenhow used the term Silicosis to describe the disease caused due to silica dust exposure (Greenberg et al., 2007). It is an occupational hazard which poses greater risk particularly for the work force engaged in construction, mining, stone crushing, cement industries, stone cutting, glass 
manufacturing and even in agriculture etc. in the developed and developing world. When the silica particles of 0.5 to 5 microns diameter are breathed into the lungs, they get embedded into the alveolar sacs and ducts and cause inflammation.

The inflammation and scarring damage the lung sacs, prevent gas exchange, and normal breathing. Damage to the lung tissue means that the capacity of the lungs to supply oxygen to the blood is reduced.Silica has been found to be a carcinogen in animal studies (in rats) and there is overwhelming evidence that the silica exposure causes lung cancer among workers with silicosis. It is most common form of Pneumoconiosis or Fibrosis. The patient becomes almost helpless and symptoms like severe cough, bloodstained sputum, continuous chest pain, and rapid weight loss are prominent leading to disablement and premature death later. Silicosis is an irreversible medical condition and has no cure. Silicosis has long latency period from exposure to development of disease and requires an interval of 6 months to 2 years of heavy exposure to massive silica. Occurrence of silicosis is directly related to the degree of exposure to silica dust. Higher the exposure more risk of developing silicosis.

Different size of the silica particles settle down in different parts of the respiratory system through the process of inhalation. 10-5 $\mu \mathrm{m}$ size silica particles reach up to upper respiratory tract causing Rhinitis and laryngitis. 5-3 $\mu \mathrm{m}$ size silica particles reaches up to the mid respiratory system and may cause Tracheaitis, bronchitis and bronchiolitis. $3-1 \mu \mathrm{m}$ size silica particles are deposited directly in the alveoli causing Asthma, COPD, and other interstitial diseases including silicosis (How Med, 2015).

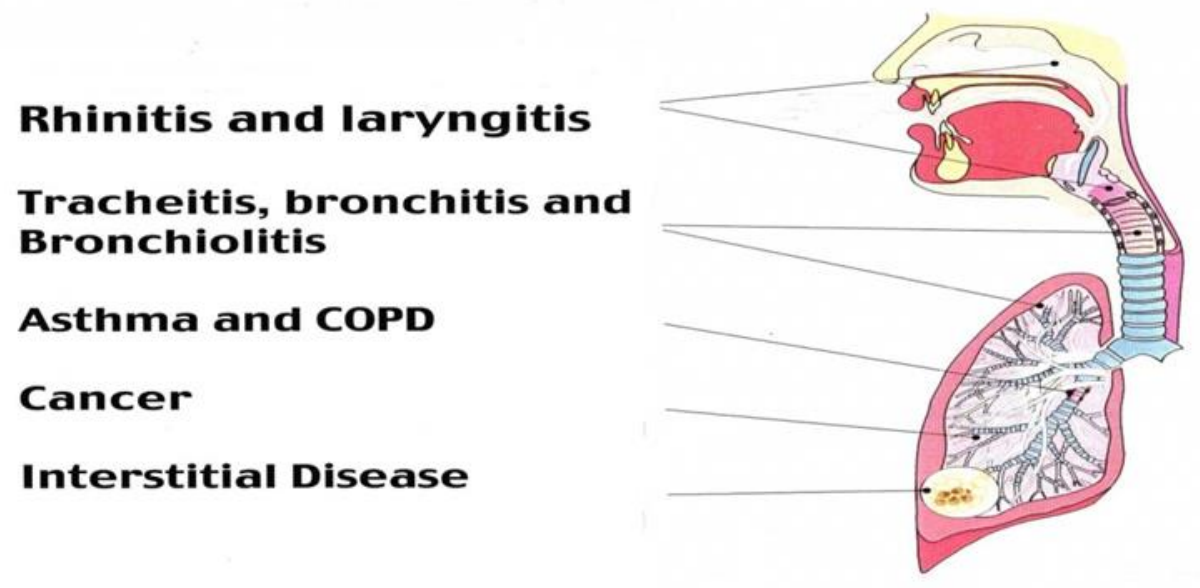

Figure 1: Parts of the Respiratory System affected due to exposure to crystalline silica

\section{Properties of Silica}

The two most occurring common elements on the surface of the earth are Oxygen and Silicon. Together, they amount for $74.32 \%$ weight and $83.77 \%$ of crustal rocks. It is abundantly available on the surface of the earth (Heaney, et al., 1994).It is transparent to gray in shades and odorless powder. If it is exposed to the eyes and skin, it causes irritation. Inhalation causes irritation to the lungs. The risk of excessive and long exposure to airborne silica poses serious health hazards and it has been known for over 100 years. Hence, crystalline silica is most widely studied chemical substance in the whole history of occupational diseases. It is rock forming mineral and 
found in abundance in nature in different forms. However, all these forms are chemically composed of $\mathrm{SiO}_{2}$. The difference in different forms lies in their atom spacing, angular relation, and lattice structure. Free silica also referred as quartz is abundantly available in our environment. The common forms of the Silicon dioxide $\left(\mathrm{SiO}_{2}\right)$ are-amorphous and crystalline. Crystalline silica is hazardous and found in many occupational environments such as mining, metal foundries and mills, agriculture settings, ship building and ship repair, construction, manufacturing facilities like paints, glass, soaps, chemicals, plastic and rubber materials. Mechanization as a result of industrial revolution of mining machinery like drillers and automatic grinders have increased the health risks because, silica which is the part of the rocks gets released into air during mining operations like dredging, drilling, and crushing etc. Agricultural activities such as harvesting, ploughing also disperses silica which is part of the soil. Manufacturing activities like cement, fibreglass, and ceramics involves silica. Construction materials include silica such as sand, concrete, cement, plaster etc. Construction activities like highways and tunnel construction, demolition, abrasive blasting, excavation, concrete works, jack hammering, and roofing also disperse silica (Madl et al., 2008).

Most common crystalline forms of silica found in work places are quartz, cristobalite, and tridymite. Rocks are composed of varying degrees of quartz naturally; sandstone (67\% silica), and granite (25-40\%). However, cristobalite and tridymite are formed when quartz or amorphous silica passes through high temperature such as lava emanating because of volcanic eruption. These also are formed in manufacturing of the refractory silica bricks for the industrial furnaces. Amorphous silica less hazardous, is also found in different forms; most common of them are diatomaceous earth (tripolite), Opal, fume silica, silica rich fiberglass, silica glass (vitreous silica), and mineral wool. Some of them are not very common and they are keatite, stishovite, and, coesite. Amorphous silica with an exception of fiberglass is not hazardous. Amorphous silica (calcined diatomaceous earth) containing crystalline silica is hazardous (fibrogenic).

\section{Silica as Carcinogen}

International Agency for Research on Cancer (IARC), a reputed institution of the World Health Organization (WHO) grouped crystalline silica exposure particularly quartz and cristobalite as a human (group no-1) carcinogen in 1997 (Ulm, et al., 2004). The National Toxicology program of the United States of America in 2000 reported that silica is human lung carcinogen; the same was reaffirmed in 2011 by it (Steenland, \& Ward, 2014). However, IARC did not find carcinogenicity of the silica in all the studies it conducted. Confounding factors like smoking, exposure to other occupational health carcinogen (diesel, radon, asbestos, arsenic) were still creating inconsistencies in establishing direct relationship between exposure to silica and lung cancer. Nevertheless, based on a meta-analysis study of a pooled data; IARC reaffirmed that silica is a carcinogen in 2009. It found crystalline silica as carcinogen based on the studies conducted on highly exposed workers from the specific industries and it concluded that cumulative exposure to respirable silica such as high intensity and duration of exposure increases lung cancer risk. Despite this direct evidence, the causal relationship between silica exposure and cancer was not universally accepted. Concerns persisted since smoking can magnify the effects of other exposures, and play dominant role in development of lung cancer. However, these inconsistencies were put to rest by a study conducted by the (Kachuri, et al., 2014); they concluded that occupational exposure to respirable silica is a risk factor for lung cancer which independent from exposure to other carcinogens and from active and passive smoking. 


\section{Hazardous Industries Generating Silica}

Exposure to respirable crystalline silica diameter $<10 \mu \mathrm{m}$ occurs in many occupational settings. When rocks and stones are broken mechanically, substances like silica flour and sand are disturbed, or handled dust comes out of it containing crystalline silica (Leung, \& Chen, 2012). Exposure to crystalline silica and its adverse impact on humans have been known for long. There are number of reports published by the United States National Institute for Occupational Safety and Health, 1974, 1983; World Health Organization (WHO), 1986; Hilt, 1993; Weil et al., 1994; details of which are summarized below in the table-1;

Table 1: Hazardous industries, activities that generate silica dust and their sources

\begin{tabular}{|c|c|c|c|}
\hline $\mathbf{S N}$ & Activity/Sector & Specific Activity/Task & Source \\
\hline $\mathbf{1}$ & Agriculture & $\begin{array}{l}\text { Ploughing, harvesting, use of } \\
\text { machinery }\end{array}$ & Soil \\
\hline 2 & $\begin{array}{l}\text { Mining and related } \\
\text { milling } \\
\text { operations }\end{array}$ & $\begin{array}{l}\text { Most occupations (underground, } \\
\text { surface, mill) and mines (metal and } \\
\text { nonmetal, } \\
\text { coal) }\end{array}$ & $\begin{array}{l}\text { Ores and associated } \\
\text { rock }\end{array}$ \\
\hline 3 & $\begin{array}{l}\text { Quarrying and related } \\
\text { milling } \\
\text { operations }\end{array}$ & $\begin{array}{l}\text { Crushing stone, sand and gravel } \\
\text { processing, monumental stone cutting } \\
\text { and abrasive blasting, slate work, } \\
\text { diatomite calcination }\end{array}$ & $\begin{array}{l}\text { Sandstone, granite, } \\
\text { flint, } \\
\text { sand, gravel, slate, } \\
\text { diatomaceous earth }\end{array}$ \\
\hline 4 & Construction & $\begin{array}{l}\text { Abrasive blasting of structures, } \\
\text { buildings } \\
\text { Highway and tunnel construction } \\
\text { Excavation and earth moving } \\
\text { Masonry, concrete work, demolition }\end{array}$ & $\begin{array}{l}\text { Sand, concrete } \\
\text { Rock } \\
\text { Soil and rock } \\
\text { Concrete, mortar, } \\
\text { plaster }\end{array}$ \\
\hline 5 & $\begin{array}{l}\text { Glass, including } \\
\text { fiberglass }\end{array}$ & $\begin{array}{l}\text { Raw material processing } \\
\text { Refractory installation and repair } \\
\text { Raw materials processing }\end{array}$ & $\begin{array}{l}\text { Sand, crushed quartz } \\
\text { Refractory materials }\end{array}$ \\
\hline 6 & Cement & Raw materials processing & $\begin{array}{l}\text { Clay, sand, limestone, } \\
\text { diatomaceous earth }\end{array}$ \\
\hline 7 & Abrasives & $\begin{array}{l}\text { Silicon carbide production } \\
\text { Abrasive products fabrication }\end{array}$ & $\begin{array}{l}\text { Sand } \\
\text { Tripoli, sandstone }\end{array}$ \\
\hline 8 & $\begin{array}{l}\text { Ceramics, including } \\
\text { bricks, } \\
\text { tiles, sanitary ware, } \\
\text { porcelain, } \\
\text { pottery, refractories, } \\
\text { vitreous } \\
\text { enamels }\end{array}$ & $\begin{array}{l}\text { Mixing, molding, glaze or enamel } \\
\text { spraying, finishing }\end{array}$ & $\begin{array}{l}\text { Clay, shale, flint, } \\
\text { sand, } \\
\text { quartzite, } \\
\text { diatomaceous } \\
\text { earth }\end{array}$ \\
\hline 9 & Iron and steel mills & $\begin{array}{l}\text { Refractory preparation and furnace } \\
\text { Repair }\end{array}$ & Refractory material \\
\hline $\mathbf{1 0}$ & $\begin{array}{l}\text { Silicon and ferro- } \\
\text { silicon } \\
\text { Foundries (ferrous and } \\
\text { non- ferrous) }\end{array}$ & $\begin{array}{l}\text { Raw materials handling } \\
\text { Casting, shaking out } \\
\text { Abrasive blasting, fettling } \\
\text { Furnace installation and repair }\end{array}$ & $\begin{array}{l}\text { Sand } \\
\text { Sand } \\
\text { Sand } \\
\text { Refractory material }\end{array}$ \\
\hline
\end{tabular}




\begin{tabular}{|l|l|l|l|}
\hline $\mathbf{1 1}$ & $\begin{array}{l}\text { Metal products } \\
\text { including } \\
\text { structural metal, } \\
\text { machinery, } \\
\text { transportation } \\
\text { equipment }\end{array}$ & Abrasive blasting & Sand \\
\hline $\mathbf{1 2}$ & $\begin{array}{l}\text { Shipbuilding and } \\
\text { repair }\end{array}$ & Abrasive blasting & Sand \\
\hline $\mathbf{1 3}$ & Rubber and plastics & Raw material handling & $\begin{array}{l}\text { Fillers (Tripoli, } \\
\text { diatomaceous earth) }\end{array}$ \\
\hline $\mathbf{1 4}$ & Paint & Raw materials handling & $\begin{array}{l}\text { Fillers (Tripoli, } \\
\text { diatomaceous earth, } \\
\text { silica } \\
\text { flour) }\end{array}$ \\
\hline $\mathbf{1 5}$ & Soaps and cosmetics & Abrasive soaps, scouring powders & Silica f10ur \\
\hline $\mathbf{1 6}$ & $\begin{array}{l}\text { Asphalt and roofing } \\
\text { felt }\end{array}$ & Filling and granule application & $\begin{array}{l}\text { Sand and aggregate, } \\
\text { diatomaceous earth }\end{array}$ \\
\hline $\mathbf{1 7}$ & Agricultural chemicals & Raw material crushing, handling & $\begin{array}{l}\text { Phosphate ores and } \\
\text { rock }\end{array}$ \\
\hline $\mathbf{1 8}$ & Jewelry & Cutting, grinding, polishing, buffing & $\begin{array}{l}\text { Semi-precious gems } \\
\text { or } \\
\text { stones, abrasives }\end{array}$ \\
\hline $\mathbf{1 9}$ & Dental material & Sand blasting, polishing & Sand, abrasives \\
\hline $\mathbf{2 0}$ & Automobile repair & Abrasive blasting & Sand \\
\hline $\mathbf{2 1}$ & Boiler scaling & Coal-fired boilers & Ash and concretions \\
\hline
\end{tabular}

Source: IARC-1997 pp 63

\section{Pathogenesis of Silicosis}

The precise pathophysiology of the silicosis disease is still a matter of research. However, several research studies point towards interactions between respirable silica particles and pulmonary alveolar macrophages. This interaction play dominant role in the development of the disease. How silica particles incite pulmonary response is not known. According to a study by the Sorptive Minerals Institute (SMI, 2006) about "differences in health risk between exposure to freshly fractured, aged silica", and the "geologically ancient" clays (fractured through natural process)" suggests that the characteristics of artificially fractured quartz (pulverized, ground, blasted, or otherwise fractured by man) make it a greater health threat than respirable quartz generated through natural geological processes. However, the nature and extent of the pulmonary alveolar response depends on the intensity of the inhaled silica particulates and the characteristics of the. It gives explanation to some extent why sandblasters and rock drillers who are intensively exposed to freshly fractured silica develop silicosis. 


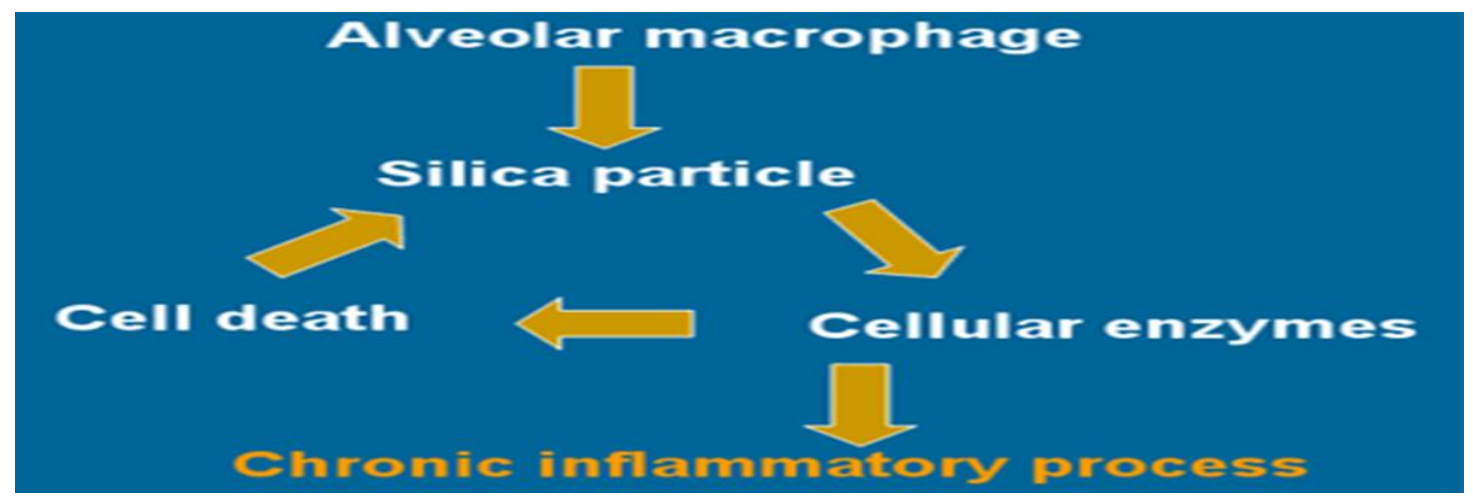

Figure 2: Impact of silica particle on lung's tissues

Source: Elcosh-Electronic Library, (2016)

It appears that the surface properties of the silica do promote macrophage activation; affected cells then release chemotactic factors and inflammatory mediators, which trigger cellular responses by the lymphocytes and leukocytes. This lead to additional macrophages. These cellular reactions release the fibroblast stimulating factors, which promote hyalinization and collagen deposition. This results in pathologic lesion in lungs. This lesion area is a kind of hyaline nodule. This nodule contains a central acellular zone with free silica and is surrounded by the spirals of collagen and fibroblasts. In addition, hyaline nodules have active peripheral zones, which are composed of macrophages, plasma cells, fibroblasts, and additional free silica particles. (Shishodiya, et al., 2011). Several in vitro and experiments on animals have been conducted to understand how alveolar macrophages and inhaled silica particles interact and induce toxicity on cells. In vitro and animal studies conducted in recent years suggest probable sequence of events after phagocytosis; the same is explained below in the picture.

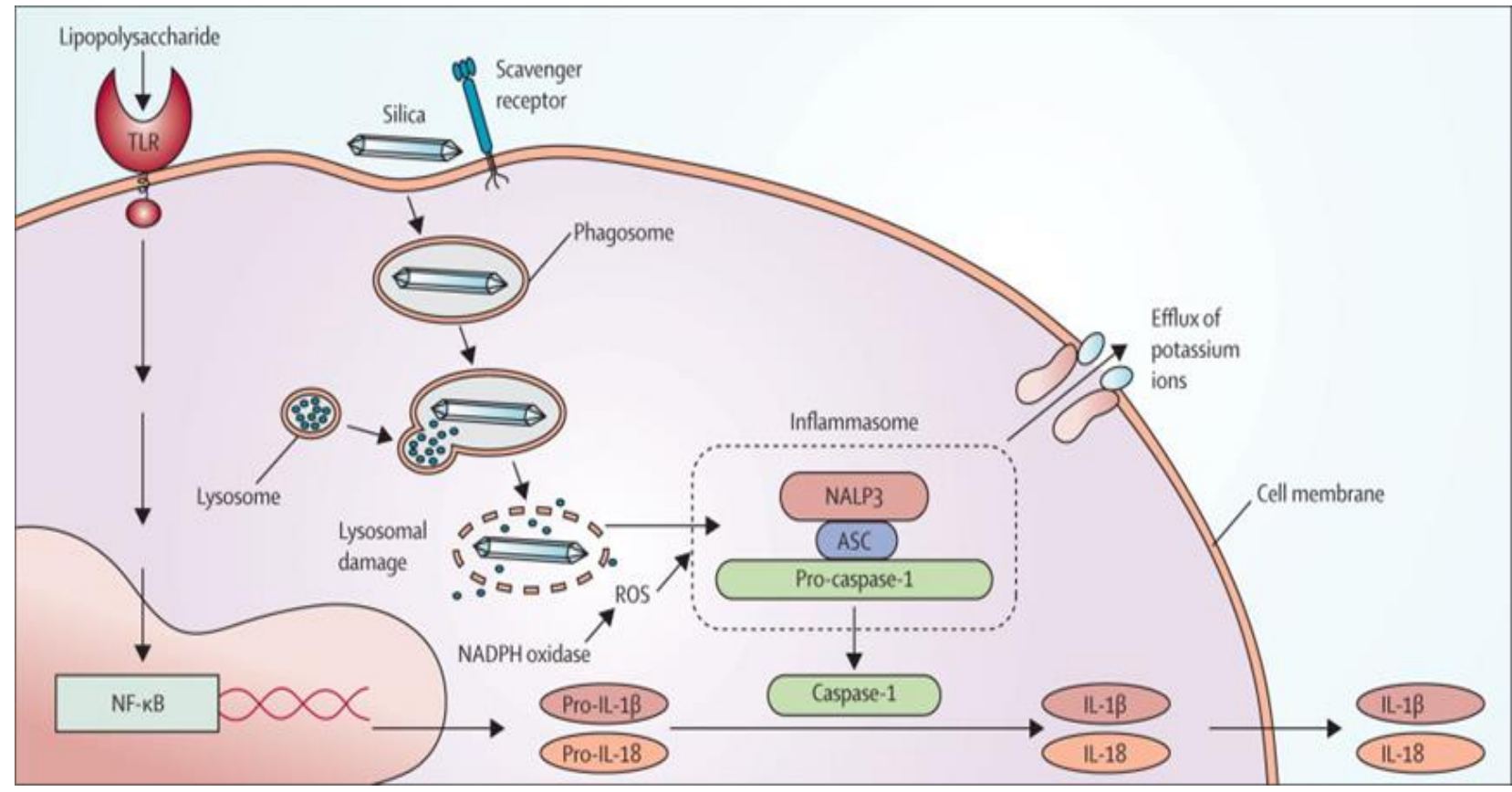

Figure 3: Activation of the NALP3 Inflammasome by a silica crystal after initial priming by a lipopolysaccharide

Source: The Lancet-2012 
In summary, following the ingestion of the silica respirable particles, alveolar macrophages generates fibroblast-stimulating factor. Due to toxicity of the ingested silica, macrophages die. This result in releasing the silica particles and fibroblast-stimulating factor. These silica particles are re-ingested by macrophages and this process is magnified. Because of the phagocytosis of silica particles, lysosomal enzymes are released rapidly into the cytosol. The release of the lysosomal enzymes causes breakdown of the intracellular organelles, which result in irreversible injury to the affected alveolar cells. However, intracellular lysosomal rupture leading to cell deaths is only circumstantial; since it is not possible to separate lysosomal rupture with that of cell deaths. There is likelihood that the macrophages are killed as a result to the damage of the plasma membrane. Pathogenesis of the silicosis may also be due to Immunologic mechanisms since in silicotic nodules Immunoglobins and abnormal Immunoglobins serum are found (Roy, 2015).

There are various types of silicosis, which include simple silicosis, silicoproteinosis, progressive massive fibrosis, and diffuse interstitial silicosis. Some of the common types are as under;

\section{Simple Nodular Silicosis}

This is the most common form of the silicosis; workers chronically exposed to silica develop the disease. Lungs of the diseased contain silicotic nodule $<1 \mathrm{~cm}$ (usually $2 \mathrm{~mm}$ to $4 \mathrm{~mm}$ in diameter). Histological examination reveals that theses nodules have web of concentrically arranged collagen. In periphery of these nodules, there are aggregates of lymphocytes and fibroblast. Within the nodule, refractile silica is also found but this is not responsible for the pathogenesis of the disease. However, free silica is associated with the disease. These nodules (Hilar nodes) get enlarged and calcified in the periphery; it is called "eggshell calcification". Evidence suggests that simple silicosis does not cause significant disability as found out by the pulmonary functions tests.

\section{Progressive Massive Fibrosis}

It is defined as nodular masses having diameter $>1 \mathrm{~cm}$ on the background of simple silicosis. These lesions are located in the upper zones of lungs and are considerable large having diameters of 5-10 cm. In many cases, these nodular formations are aggregate of nodules of simple silicosis. They are also called as "conglomerate silicosis". These lesions (nodular formations) of Tuberculosis in lungs of workers also resemble to PMF giving rise suspicion that PMF is due to Tuberculosis. PMF is closely related to the amount of silica in the lungs. Disability is caused due to destruction of the lung tissues as a result of the formation of nodules in the lungs and their calcification.

\section{Acute Silicosis}

It results from massive exposure to respirable silica, which get released during blasting or grinding operations. It is associated with diffused fibrosis of the lungs devoid of silicotic nodules. Alveolar sacs get filled up with dense eosinophils materials resembling to alveolar lipoprotenosis. The disease progress very fast over a few years as contrast to other forms of the disease; however, other forms of the disease take decades for the disease to reach advance stage. Examination of radiographs, show diffuse linear fibrosis and decreased lung volume. 


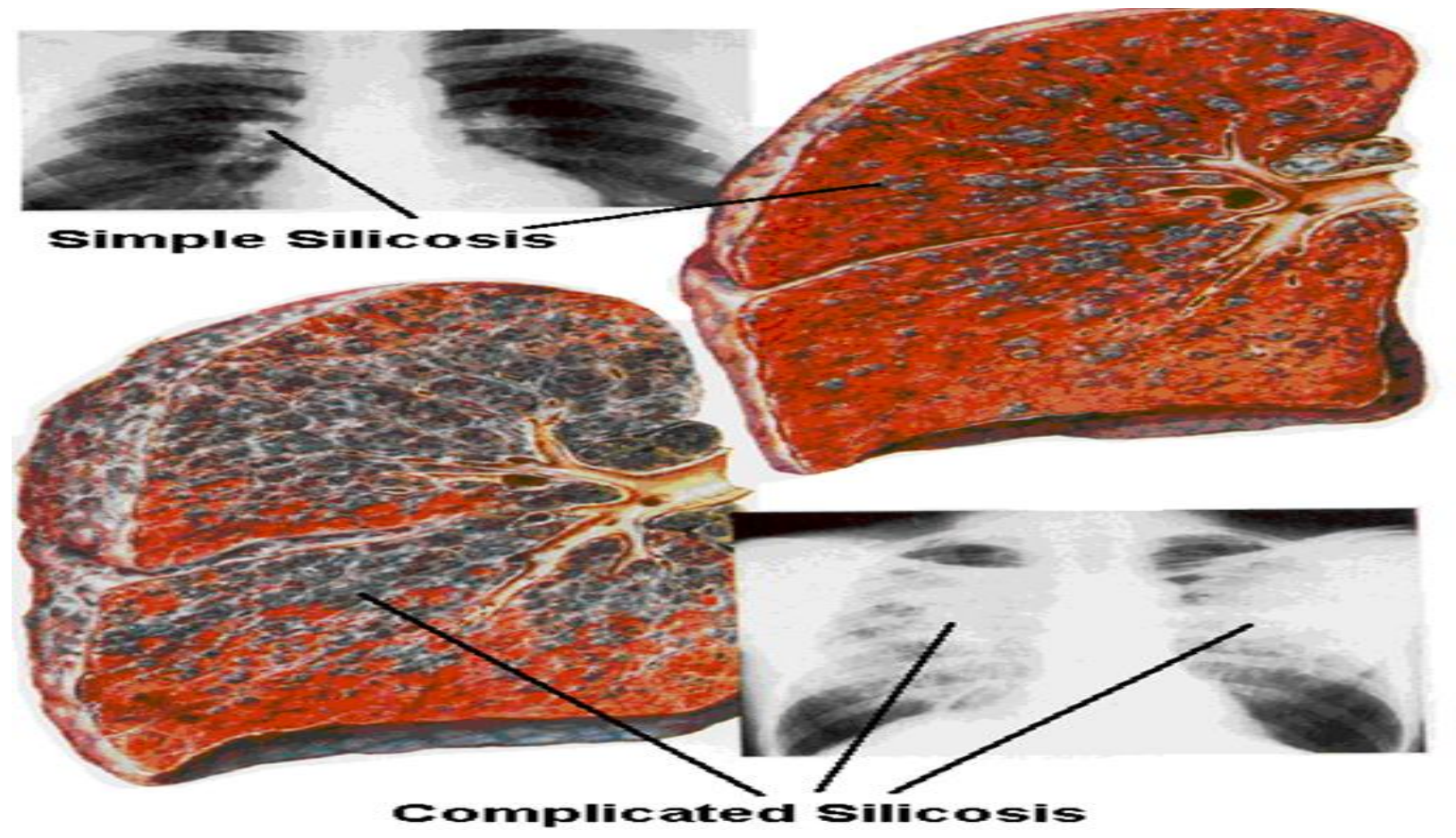

Figure 4: Chest X Rays of the Silicosis patients

Source: NIMH Nagpur-2014

\section{Clinical Symptoms}

Silicosis is an asymptomatic disease largely until it advances to the Progressive Massive Fibrosis (PMF) stage. Patient may have no symptoms despite radiographic evidence suggesting the presence of the disease. The symptoms of the disease resembles to that of bronchitis. There is excessive discharge of the sputum due to exposure to dust or sometime secondary bacterial infection causes sputum. Dyspnea on exertion is a common and frequent complaint of the patients; however, complaints are very frequent in presence of other diseases such as tuberculosis or bronchitis. The literal word meaning of "dyspnea" is bad breathing but in medical sciences; it means shortness of breath or distress in breathing. The severity of dyspnea is directly related with the progression of the disease. The complaints of chest pain and hemoptysis are regular phenomenon in the patients. Hemoptysis refers to coughing of blood or producing bloody sputum from the lungs or airways. In cases with acute silicosis, there is a severe dyspnea with weight loss. The disease is rapidly progressive which leads to death because of severe Hypoxemicventilatory failure. Hypoxemicventilatory failure refers to presence of inadequate amount of $\mathrm{O}_{2}$ in the blood (Shishodiya at al., 2011).

\section{Diagnosis}

Diagnosis of the silicosis disease takes existence of several risk factors simultaneously; they are as under;

1) Exposure to silica dust- Occupational History

2) Radiologic findings-simple chest $X$ rays

3) Ruling out other possible diseases 


\section{Occupational History}

1) Silicosis being a an occupational disease it is important to take the following details into account;

2) A detailed occupational case history must be gathered with a view to estimateaccumulated exposure to crystalline silica. This is difficult job for the clinicians particularly in cases where there is frequent job changes by the affected person. Nevertheless, past and present job's activities' details and duration of exposure to silica dust must be recorded.

3) Detailed job description

4) Protective measures, institutional practices like wet drilling, water jet cutter, provision of ventilation, dust extraction etc. and safety and practices in place at individual levels such as use of masks

\section{Standard Chest X-Ray}

Experienced and competent clinicians are able to make diagnosis of the silicosis on the basis high quality chest $\mathrm{X}$ rays. With a purpose to standardize the diagnosis process, the International Labor Office (ILO) has developed classification system for coding radiological changes; this classification system contains five components;

1) Radiographs' technical quality aspects: 1: Good with no defect, 2: acceptable with no defect, 3: poor, acceptable with some technical defect, and 4: unacceptable for classification purposes

2) Parenchymal changes: size, profusion, shape (rounded or irregular) and site

3) Opacities-small: They are ( $3 \mathrm{~mm}$ to $10 \mathrm{~mm}$ in dimension) described according to profusion

4) Opacities-large: Opacities having a dimension more than $10 \mathrm{~mm}$ are considered as large opacities. They are further grouped into A, B, and $\mathrm{C}$ categories according to their combined dimensions and the location in the lungs.

5) Pleural abnormalities: They are reported with respect to types such as pleural plaques, diffused pleural thickening; their location whether they are found in chest wall, in diaphragm or other; presence of calcification and their extent (length of the involvement of the chest wall).

6) Symbols: Their use is relevant because they provide useful information on exposure to dust and etiological aspects of the disease, however use of symbols are obligatory.

The ILO introduced use of digitized images in 2011 and it provides 22standardized images. In addition, it gives technical details how radiographs must be read by using monitors. The specification of the monitors prescribed by the ILO for the diagnostic radiology are width (54 $\mathrm{cm}$ ), luminance ratio $\left(250\right.$ candelas $\left./ \mathrm{m}^{2}\right)$, and pixel size (maximum 210 microns).

\section{Ruling out other Diseases}

Clinician performs several other differential diagnostic tests to rule out other diseases in case-tocase basis. Some of these complimentary tests are as under;

1) Lung Function Tests: These tests are helpful in detecting severity of the lungs involvement so that the patient can be guided to make occupational choices in future. Spirometry is used to determine the lung function. This is usually conducted during the diagnosis and at check-ups to evaluate deterioration of the lung function. 
2) High Resolution Computed Tomography (HRCT): The HRCT technique is useful in observing abnormalities in terms of lung architecture and vascular anatomy such as nodules calcification in certain cites of lungs. It is reported that HRCTs are more sensitive than X-rays in the diagnosis of the silicosis. However, several study reports that the technique has more disadvantages than the advantages. It does not have clear enough standards for reading the HRCTs, which increase the risk of false positive cases in the diagnosis. Generalized use of this technique may lead to observing pulmonary nodules of uncertain significance and as a result create confusion in the diagnosis process. In addition, based on these findings employer might declare the worker unfit for the job. Hence, its use in silicosis diagnosis is not recommended (ILO, 2011).

\section{Treatment and Prevention of Silicosis}

A chronic and progressive disease has no effective treatment. Patients can only be provided supportive care. In some cases, lung transplantation may be considered. The disease may continue to progress even after cessation of the exposure to silica dust (Bang, et al, 2015). Depending on severity of the disease, it causes morbidity, disablement and deaths. Since there are no effective treatment to either, reverse the lesions or slow down its progression, hence preventive measures are the only solution to the problem.

Primary prevention: This is to be done by keeping the exposure under permissible limit. In USA, the Occupational Safety and Health Administration (OSHA) has set the standards for permissible limit of exposure to crystalline silica, which is not hazardous. It has laid down a rule that the worker's exposure to hazardous silica shall not exceed an 8-hour time weighted average limit. In addition, it has given a mathematical formula for calculating the exposure limit as explained below

\section{$\underline{10 \mathrm{~mm} / \mathrm{m}^{3}}$ \\ (Percentage of quartz) +2}

Suppose, a specific material handled by the worker has $8 \%$ silica quartz in it; once the above formula is applied; it comes out one cubic millimeter. This becomes the exposure limit and worker must not exceed this exposure limit. Alternatively, if the material handled by the workers consists of $48 \%$ silica quartz then in that case the limit is 0.2 milligrams per cubic meter (MIA, 2008). However, the monitoring and enforcements of the OSHA's standards measures are beyond the responsibility of the physicians. Moreover, present silica dust exposure limit does not eliminate the risk of the silicosis completely (Álvarez, et al., 2015).

Secondary prevention: The objective of the secondary prevention is to diagnose the case, to control the progression of the disease, and to prevent complications. Safety precautions in work places and health monitoring should be available to all the workers exposed to crystalline silica. Workers should be subjected to the medical examination such as x-rays, and pulmonary function test, before entering to the stone trade to determine the baseline of the worker. There should be ongoing medical checkups in regular intervals not exceeding more than three years (MIA, 2008). When a worker is, diagnosed positive regular checkups are to be performed every 1-3 years depending on the clinical form, radiology, and functional involvement. Milder cases can undergo checkups less often. There should be an effort to screen the additional workers in 
industries where the case has been identified. Diagnosed cases must be informed about the role of silica in the disease and its synergy with tobacco use with that of development of the disease with a view to counsel them for the cessation of the tobacco use. Since silicosis is a chronic disease, it makes patients with silicosis vulnerable to infections from Streptococcus pneumoniae, influenza, hence they need to be vaccinated against these diseases (Álvarez, et al., 2015).

Tertiary prevention: Once a worker is diagnosed positive, his exposure to silica and other irritants further must be avoided to check the progression of the disease since there is no specific treatment of the disease. Patients should be provided supportive care, which includes cough medicine, bronchodilators, and oxygen, if there is a need. Patients are prescribed antibiotics to prevent respiratory infections. Examination to detect Tuberculosis must be conducted and treated as per the existing standards since exposure to silica is believed to interfere with the body's immune response to the pathogens that cause the TB. Cases with silicosis must undergo skin tests to determine TB status. All the positive cases of TB are to be treated with anti TB drugs as per the existing norms. For the severe cases, they have to have a lung transplantation surgery done (Dugdale, et al., 2016).

\section{Disablement Assessment}

Silicosis is a notifiable disease under the law. Employer where the worker is employed and the medical facility where he is diagnosed have to report the health status of the worker to the appropriate authority as prescribed under the law. Following which a team of occupational health specialists, comprising of a pulmonologist, radiologist and other in the light of existing laws and guidelines have to determine the degree and of the disability on the basis of medical reports of the worker with a view to compensate the affected worker. This assessment is only undertaken with the cases having definite diagnosis of silicosis. This team is to determine the clinical form of the disease such as simple or complicated silicosis and its classification as per the ILO standards. In addition, expert team is to assess the permanent respiratory impairment irrespective of whether it has arises as a result of silicosis or something else. If the impairment has arisen from something else; then the cause of the same must be explained. The status of the TB in the worker must also be declared since regulation requires specifying such cases in different occupational disablement categories. The diagnosis has to be robust since it has serious ramifications on the worker's social and working life (Álvarez, et al., 2015).

WHO came up with a new metric strategy to evaluate the disability in terms of disability adjusted life year (DALY). This metric is a measure to quantify injuries, risk factors and disease burden. It is based on years of life lost due to premature death and years of life lived with disability. DALY for a disease or health condition is calculated as a total years of life lost (YLL) due to premature Mortality or years lost due to Disability (YLD) a consequence of disease or health condition.

Disability Adjusted Life Years Lost $(\mathrm{DALY})=$ Years of Life Lost (YLL) + Years of Life Lost due to Disability (YLD).

DALY=YLL+YLD

YLL refers to number of fatalities $x$ average life expectancy at the age when death happens. The formula for the same is as under; 
YLL=N x L

(Where $\mathrm{N}$ refers to number of fatalities and L standard life expectancy at the time of death in years)

For calculating YLD of any specific diseases or health condition, number of related cases/incidents during a time period (I) $\mathrm{x}$ average period of disease (i.e. till death or remission) (L) and weightage which reflects severity of the condition or disease in a scale of 0-1 where o referring to perfect health and 1 referring to death (DW) (WHO, 2017).

\section{YLD=I x DW x L}

However, this method of calculating compensation has certain demerits due to non-availability of the required data such as prevalence of silicosis for a large population, total population exposed to silica, survival of the silicosis patients after diagnosis and disability weights etc.

\section{Global Prevalence of Silicosis}

Silicosis cases have been found worldwide. 30-50\% of workers engaged in primary and high-risk industries in developing countries may be the victims of the silicosis or other pneumoconiosis. WHO reported that annually 30,000 people die due to pneumoconiosis caused by airborne particulate (WHO, 2007).Silicosis burden is substantial globally. In 2000, around 8800 deaths were attributed to silicosis worldwide. (NIOH \& PAHO, 2009). In developed countries like USA during 2001, 164 deaths and in 2010, 101 deaths were reported due to silicosis and in USA, 1.7 million workers are exposed to siliceous dust out of which $10 \%$ workers are at risk to contract the disease (Thomas \& Kelley, 2010). In West Virginia, Hawk Nest's (USA) silicosis were reported that out of 5000 workers 764 were dead and 1500 developed because of tunneling, blasting, and drilling activities (CDC, 2005). According to the summit on elimination of silicosis jointly organized by the WHO and ILO in 2003; around 3000 in Germany, Japan and Australia > 1000 cases were reported annually. In France, around 300 cases were reported (MIA, 2008). In Canada, amongst 400 gold miners during 1925-26 in Porcupine 46 workers were diagnosed with the silicosis (Cunningham, 1930).

In developing countries situation is at epidemic level. In China $>5$ million are exposed to deadly silica; and $>24,000$ deaths occurred due to silicosis from 1991-1995. Scenario in Brazil was one of the worst $>6.6$ million exposed to silica; in Minas Girais province alone $>4500$ people became the victim of the disease (Ferreira et al., 2008). In Brazil's drought affected northeast, stone is found in layers with very silica content (97\%) causing silicosis in $26 \%$ of the workers. A study conducted in Petropolis province in Brazil reported $53.7 \%$ silicosis amongst stone artisans (Antão, 2004). South Africa had 600,000 silicosis cases mainly mines workers (MIA, 2008). In 2003, International Social Security Association reported that silicosis as the biggest occupational health challenge in Rwanda. In Latin American countries mines' workers upto 37\% suffer from the silicosis. In Columbia alone there are around 1.8 million people at risk to develop silicosis (Luton, 2007).

\section{National Scenario on Silicosis}

In India, first case was detected in Kolar gold mines in 1940. Epidemiological surveys conducted time-to-time show that the problem is more severe in unorganized sector. These studies suggest that prevalence of the disease ranges from $3.5 \%$ in ordnance factory to $54.6 \%$ in slate pencil 
industries etc. This fluctuating prevalence is the function of the nature of the job, concentration of the silica in work environment, and duration of the exposure. However, these surveys are cross sectional studies hence take into account only surviving population.

Table 2: Details of the studies and prevalence of silicosis in India

\begin{tabular}{|l|l|l|l|}
\hline SN & \multicolumn{1}{|c|}{ Industry/Sector } & Prevalence & \multicolumn{1}{c|}{ Reference/Year } \\
\hline 1 & Gold Mines & 8.84 & Caplan and Burden, 1947 \\
\hline 2 & Gold Mines Mines \& Mica Processing & 13.9 & Gowda, 1983 \\
\hline 3 & $\begin{array}{l}\text { Mica } \\
\text { Industries, Bihar }\end{array}$ & 4.1 & Chief Advisory Factories, 1953 \\
\hline 4 & Manganese Mines & 30.4 & $\begin{array}{l}\text { Chief Advisor of Factories, } \\
1961\end{array}$ \\
\hline 5 & Lead and Zink Mines in Rajasthan & & Saini et al., 1984 \\
\hline 6 & Stone cutters, Kashmir & 20.0 & Sethi and Kapoor, 1982 \\
\hline 7 & Stone cutters & 25 & Gupta et al., 1972 \\
\hline 8 & Stone Cutters & 35.2 & Samal et al., 1986 \\
\hline 9 & Foundries Workers & 27.2 & Viswanathan et al., 1972 \\
\hline 10 & Ordnance Factory & 3.5 & Sadhu et al., 1995 \\
\hline 11 & Agate Workers & 38.0 & Srivastava et al., 1988 \\
\hline 12 & Glass Bangle & 7.3 & Saiyed et al., 1985 \\
\hline 13 & Slate Pencil Workers & 54.6 & Gangopadhyay et al., 1994 \\
\hline 14 & Mica mines and mica processing & 5.2 & NIOH, 1986 \\
\hline 15 & Quartz Crushing & 12.0 & NIOH, 1987 \\
\hline 16 & Stone quarry & 22.0 & NIOH, 1989 \\
\hline 17 & Sand Grinding & 27.8 & Saiyed et al., 1995 \\
\hline 18 & Ceramics \& Potteries & 15.1 & \\
\hline
\end{tabular}

Source: ICMR-1999

\section{Silicosis Scenario in Rajasthan}

Silicosis has emerged at epidemic level in Rajasthan. A study in 1992-94 carried out by the Desert Medicine Research Center, Jodhpur reported that 9.9\% sandstone workers had silicosis. A Jodhpur based NGO, Gramin Vikas Vigyan Samiti GRAVIS, and a Delhi based NGO, Participatory Research in Asia (PRIA) found that around 10\% mines workers were suffering from the silicosis. A study conducted by the National Institute of Miners Health with the support of Association of Rural Advancement Through Voluntary Action and Local Involvement (ARAVALI), an agency of Government of Rajasthan, Dang Vikas Samiti (DVS), a Karauli based NGO with the poor mines workers of Karauli revealed that more than $74 \%$ of them were suffering from the silicosis. These 101 people belonged to more than 26 villages of the Karauli district (Sishodiya, et al., 2014).

Details of the confirmed cases of silicosis from January to December 2016, according to the Medical \& Health Services, Government of Rajasthan are as under; 
Table 3: Number of silicosis cases issued certificate by the Pneumoconiosis Medical Boards (PCBs) during 2015-2016

\begin{tabular}{|c|c|c|c|}
\hline S.No. & $\begin{array}{l}\text { Name of } \\
\text { District }\end{array}$ & $\begin{array}{l}\text { No. of Certificate issued by } \\
\text { district Pneumoconiosis } \\
\text { boards upto } 31 \text { Dec } 2015\end{array}$ & $\begin{array}{l}\text { No. of Certificate issued by } \\
\text { district Pneumoconiosis } \\
\text { boards Jan } 16 \text { to Dec } 16\end{array}$ \\
\hline 1 & Ajmer & 0 & 15 \\
\hline 2 & Alwar & 0 & 32 \\
\hline 3 & Bansawara & 0 & 5 \\
\hline 4 & Baran & 0 & 0 \\
\hline 5 & Barmer & 28 & 40 \\
\hline 6 & Bharatpur & 275 & 708 \\
\hline 7 & Bhilwara & 102 & 862 \\
\hline 8 & Bikaner & 0 & 1 \\
\hline 9 & Bundi & 0 & 0 \\
\hline 10 & Chittarugarh & 1 & 13 \\
\hline 11 & Churu & 0 & 0 \\
\hline 12 & Dausa & 177 & 453 \\
\hline 13 & Dhaulpur & 0 & 0 \\
\hline 14 & Dungarpur & 0 & 0 \\
\hline 15 & Ganganagar & 0 & 0 \\
\hline 16 & Hanumangarh & 0 & 0 \\
\hline 17 & Jaipur & 0 & 6 \\
\hline 18 & Jaisalmer & 0 & 0 \\
\hline 19 & Jalore & 59 & 76 \\
\hline 20 & Jhalawar & 0 & 39 \\
\hline 21 & Jhunjhunu & 0 & 11 \\
\hline 22 & Jodhpur & 214 & 115 \\
\hline 23 & Karauli & 0 & 65 \\
\hline 24 & Kota & 0 & 0 \\
\hline 25 & Nagaur & 0 & 364 \\
\hline 26 & Pali & 0 & 112 \\
\hline 27 & Pratapgarh & 0 & 0 \\
\hline 28 & Rajsamand & 0 & 33 \\
\hline 29 & S. Madhopur & 0 & 0 \\
\hline 30 & Sikar & 0 & 3 \\
\hline 31 & Sirohi & 0 & 361 \\
\hline 32 & Tonk & 0 & 0 \\
\hline \multirow[t]{2}{*}{33} & Udaipur & 0 & 30 \\
\hline & Total & 856 & 3344 \\
\hline
\end{tabular}

Source: Shishodiya, P. K., Dr. (2017, March 15) 
State Government so far has made effort to rehabilitate affected mines workers by various ways. It is paying INR 100,000.00 (approx. 1500) to the person who is certified as silicosis case and INR 300,000.00 to (approx. 4500) the legal heir of the person who died with silicosis.

Table 4: District-wise list of Building and Other Construction Workers' Welfare Board (BOCW) silicosis beneficiaries and relief disbursed as on $23^{\text {rd }}$ February 2017

\begin{tabular}{|l|l|c|c|c|c|c|}
\hline S.N. & $\begin{array}{c}\text { Name of the } \\
\text { District }\end{array}$ & $\begin{array}{c}\text { No of } \\
\text { beneficiaries } \\
\text { examined in } \\
\text { Health } \\
\text { Screening } \\
\text { Camps }\end{array}$ & $\begin{array}{c}\text { Noneficiaries } \\
\text { detected } \\
\text { with } \\
\text { Silicosis }\end{array}$ & $\begin{array}{c}\text { No of } \\
\text { Beneficiaries } \\
\text { provided } \\
\text { relief * }\end{array}$ & $\begin{array}{c}\text { Amount } \\
\text { of } \\
\text { Relief } \\
\text { given } \\
\text { Rs in } \\
\text { Lakhs }\end{array}$ & $\begin{array}{c}\text { No of } \\
\text { applications } \\
\text { pending for } \\
\text { relief }\end{array}$ \\
\hline 1. & Karauli & 146 & 95 & 58 & 58 & 01 \\
\hline 2. & Dausa & 267 & 164 & $346(26)$ & 398 & $323 * *$ \\
\hline 3. & Dholpur & 124 & 39 & $14(01)$ & 16 & 05 \\
\hline 4. & Alwar & 100 & 22 & 00 & 00 & 00 \\
\hline 5. & Bharatpur & 116 & 25 & 04 & 04 & 00 \\
\hline 6. & Udaipur & 161 & 61 & 01 & 01 & 00 \\
\hline 7. & Rajsamand & 46 & 09 & 06 & 06 & 00 \\
\hline 8. & Chittodgarh & 43 & 06 & $05(01)$ & 07 & 01 \\
\hline 9. & Bhilwara & 134 & 38 & $31(01)$ & 33 & 17 \\
\hline 10 & Jodhpur & 17 & 09 & 05 & 05 & 00 \\
\hline 11. & Sirohi & 614 & 279 & $212(21)$ & 254 & 73 \\
\hline 12. & Jhalawad & 112 & 48 & $40(01)$ & 42 & 02 \\
\hline 13. & Bundi & 82 & 18 & 00 & 00 & 00 \\
\hline 12. & Jaipur & 136 & 09 & $01(01)$ & 03 & 00 \\
\hline 13. & Jhunjhinu & 14 & 00 & 00 & 00 & 00 \\
\hline 14. & Sikar & 39 & 01 & 00 & 00 & 00 \\
\hline 15 & Ajmer & 153 & 30 & 02 & 02 & 0 \\
\hline 16. & Nagaur & 128 & 37 & 03 & 03 & 19 \\
\hline 17 & Pali & 07 & 00 & $35(01)$ & 37 & 05 \\
\hline 18 & Jalore & 51 & 14 & 00 & 00 & 62 \\
\hline 19. & Badmer & 00 & 00 & 28 & 28 & 06 \\
\hline 20. & Jaisalmer & 00 & 00 & 09 & 09 & 00 \\
\hline & Total & $\mathbf{2 4 9 0}$ & $\mathbf{9 0 4}$ & $\mathbf{8 0 0 ( 5 3 )}$ & $\mathbf{9 0 6}$ & $\mathbf{5 1 4}$ \\
\hline Source & Shishodya & $(2017$ & & & & \\
\hline
\end{tabular}

Source: Shishodiya, P. K., Dr. (2017, March 15)

* $\quad$ Fig in parenthesis indicates No. of beneficiaries provided relief after death.

** Large pendency in Dausa is because of irregularities detected in issue of silicosis certificates by Pneumoconiosis Medical Board.

*** In addition to health screening camps, beneficiaries

However, in Karauli district till February 2017, 2758 cases have been diagnosed with silicosis out of which 2267 have received compensation from the Government (Bhardwaj, V., Dr., 2017). 


\section{Objective 1: To assess magnitude of Silicosis in the district}



Figure 4: Historic pond made of sandstone in Karauli

Rani Ka Talab, Karauli (Queen's Pond, Karauli)

\section{Methodology}

\section{Sampling Frame}

A village was taken as a sample unit in this cross sectional survey. A sampling frame of all villages (with approximately 1000 population) was sought from the district administration for each of the 4 area/regions/divisions of the district namely Sapotara, Hindaun, Mandaryal, and Karauli, and then one village was selected randomly from this sampling frame from each division. However, from Hindaun and Karauli divisions two villages each were selected since most of the villages and the district are of $<500$ population. Hence, total 6 villages were selected from 4 regions of the district. Total of 6975 comprising of 2094 from Mamchari, 1047 from Palanpur, 1026 from Binega, 710 from Arampura-Mahu, 632 from Garhi Ka Gaon, and 566 from Chaube Ki Guwari.

\section{Justification for Sample Size of the Study}

It was assumed that the prevalence of silicosis in adult population of 3.49 lakh would be around $12 \%$ in the district. In that case a sample of 162 confirmed cases would be sufficient to provide true picture in the population with a $95 \%$ confidence and $10 \%$ relative precision. In a village with a population of $1000(\mathrm{~N})$, approximately $60 \%$ may be adults (reduced $\mathrm{N}=600$ ) and among the adults if approximately half (50\%) are assumed to be exposed to the occupation (reduced $\mathrm{N}=300)$, finally $12 \%$ of these exposed adults $(\mathrm{n}=36)$ will form our study subjects. Even if we assume $20 \%$ may not be tracked, still in a village of 1000 population we can get 30 study subjects. Therefore, for getting 162-study sample we need to survey approx. 6000 population.

\section{Inclusion Criteria and Method}

All the persons 6975 of 6 villages of the 4 major divisions of the district were target population for inclusion in this study. The followings were the specific criteria for including or excluding a subject in or out of the study. 
1) All the adults population of the village

2) Person having respiratory symptoms/problems with a known history of mining

All the households of the villages selected for gathering data having people with respiratory problems with known history of mining or mining related work were visited with a help of local people and volunteers of an NGO, Dang Vikas Sanstha (DVS, Karauli) working in the area. Subjects were administered SGRQ after obtaining their consent in writing.

\section{Tool}

St. George Respiratory Problem Questionnaire (SGRPQ) - Hindi Version

The SGRPQ is a tool developed two decades ago. It is one of the most widely used disease specific quality of life (QoL) questionnaires in Chronic Obstructive Pulmonary Diseases (COPD) (Paap, et al., 2013). It was originally developed to use it in patients with COPD and Asthma but it is also used in patients with Bronchiectasis, Kyphoscoliosis, and Sarcoidosis and Cystic Fibrosis. The SGRPQ questionnaire is divided into two parts; part I produces the symptoms score and part II the activity and impact scores and also gives total score (Jeffery, et. Al, 2014). SGRPQ is self-administered under supervision; patients are required to complete the questionnaire by himself or herself, but someone who is well versed with the questionnaire must be available to guide the patient, if required. However, it is designed to measure the patients' opinion and not someone else's opinion.

Part 1 (questions 1-8): covers the patients' recollection of their symptoms for the past 1 month to 1 year. It is not designed to be an accurate epidemiological tool; its purpose is to assess perceptions of the patients' recent respiratory difficulties. Symptoms domain assesses frequency and severity of the respiratory symptoms. Part II (questions-9-16): addresses current state of the patient. The activity score just measures difficulties to patient's daily physical activity. The impact scores covers wide range of difficulties encountered in psychosocial spheres of the patient. In brief, activity scores demonstrate effects of breathlessness on mobility and physical activity whereas impact score demonstrates psychosocial impact of the disease.

SGRPQ consists of dichotomous (Yes/No), and Likert type questions. Scores are weighted in such a way that every domain score and the total score range from $0-100$, with higher scores indicating poor Health Related Quality of Life (HRQoL). SGRPQ (95\% confidence intervals) for SGRPQ scores in normal subjects with no history of respiratory disease.

Table 5: SGRPQ scores in normal subjects with no history of respiratory disease

\begin{tabular}{|c|c|c|c|c|c|}
\hline $\mathbf{N}$ & Age-Years & Symptoms Score & Activity Score & Impacts Score & Total Score \\
\hline 74 & 46 & 12 & 9 & 2 & 6 \\
& Range $17-80$ & $(7-12)$ & $(7-12)$ & $(1-3)$ & $(5-7)$ \\
\hline
\end{tabular}

\section{Area of Survey}

Karauli is one of the $31^{\text {st }}$ districts of state of Rajasthan. Geographically the state of Rajasthan shares its boundary with Pakistan. Internally, state shares boundaries with the state of Uttar Pradesh, Haryana, Madhya Pradesh and Gujarat. District Karauli gets its name from the name of the town where its head quarter is housed. It was the capital of the erstwhile capital of princely 
state of Karauli. District Karauli with its five tehsils namely Karauli, Hindaun, Nadoti, Sapotara, and Todabhim came into existence on July $19^{\text {th }}$ 1997. It was carved out from the district of Sawai Madhopur. Karauli along with other three adjacent districts namely Bharatpur, Dhaulpur, and Sawai Madhopur are parts of Bharatpur division. District Karauli with its six tehsils namely Karauli, Hindaun, Nadoti, Sapotara, Mandaryal, and Todabhim came into existence on July 19, 1997. The compositions of these six tehsils are as under;

Table 6: Tehsils of Karauli

\begin{tabular}{|l|l|c|}
\hline SN & Name of Tehsil & Number of Villages \\
\hline 1 & Todabhim & 151 \\
\hline 2 & Nadoti & 106 \\
\hline 3 & Hindan & 165 \\
\hline 4 & Karauli & 212 \\
\hline 5 & Sapotara & 177 \\
\hline 6 & Mandaryal & 77 \\
\hline \multicolumn{2}{|l|}{ Total } & $\mathbf{8 8 8}$ \\
\hline
\end{tabular}

According to Human Development Report of Rajasthan (HDR) 2008; district Karauli is one of the most backward districts of Rajasthan as it ranked $22^{\text {nd }}$ in terms of development amongst all the 32 districts of the state of Rajasthan. However, according to Census 2011, Karauli district ranks $22^{\text {nd }}$ in terms of population, $23^{\text {rd }}$ in terms of area and $13^{\text {th }}$ in terms of population density in the state of Rajasthan. Karauli tehsil has 212 villages, highest amongst all other tehsils whereas Mandaryal has the lowest (77) villages. Majority of the population of the district (85\%) lives in rural areas whereas (15\%) lives in urban areas. The sex ratio is significantly lower (861/1000) than that of the state (928/1000). Literacy rate of the district is 66.2 almost equal to the state Literacy rate (66.1). The district has the highest concentration of SC (24.3\%) and ST (22.3\%) population in the state.

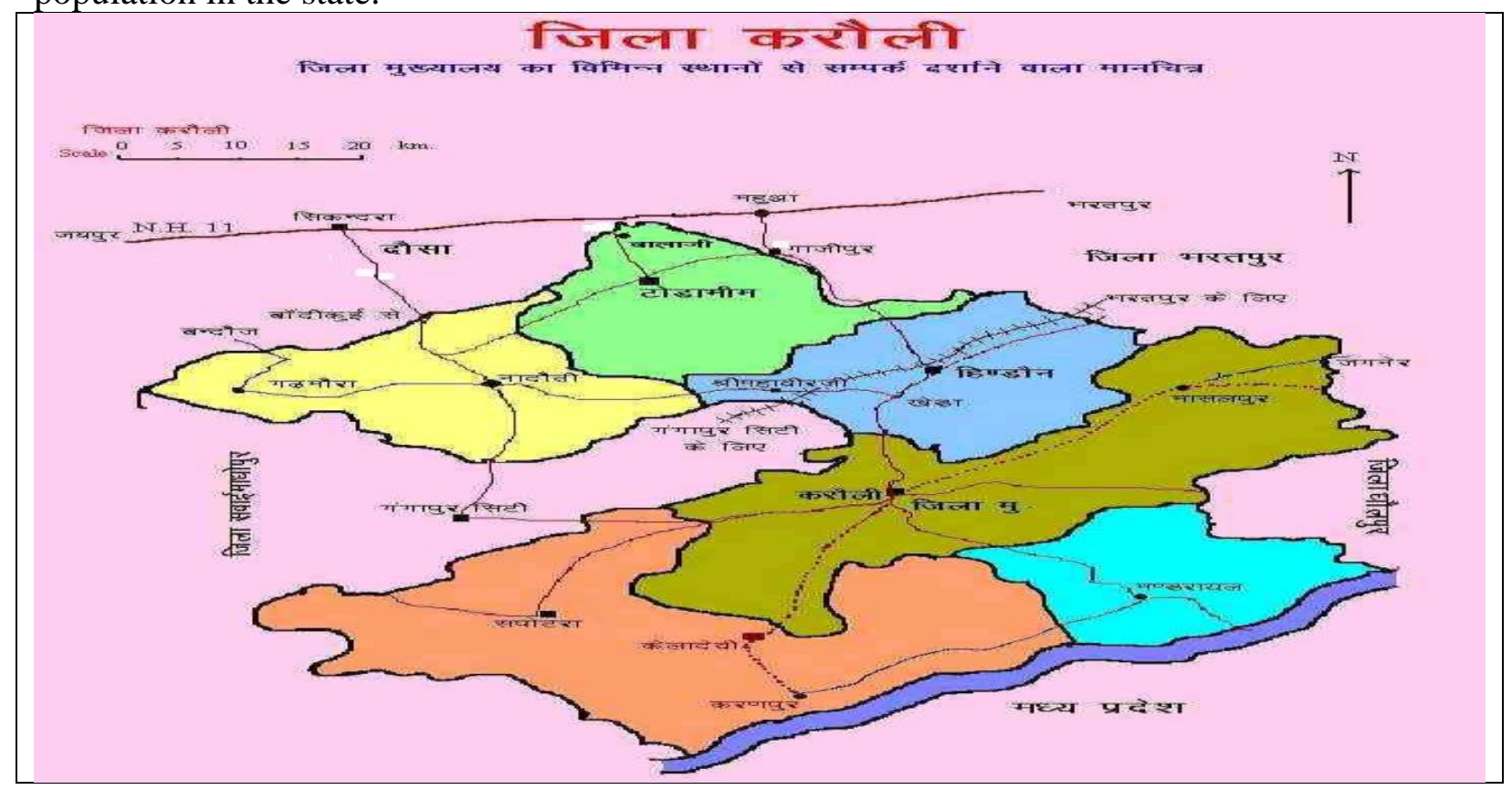

Figure 5: Karauli district 
The economy of the Karauli is dependent on agriculture; more than $70 \%$ people are either cultivators or agriculture laborers in the district.

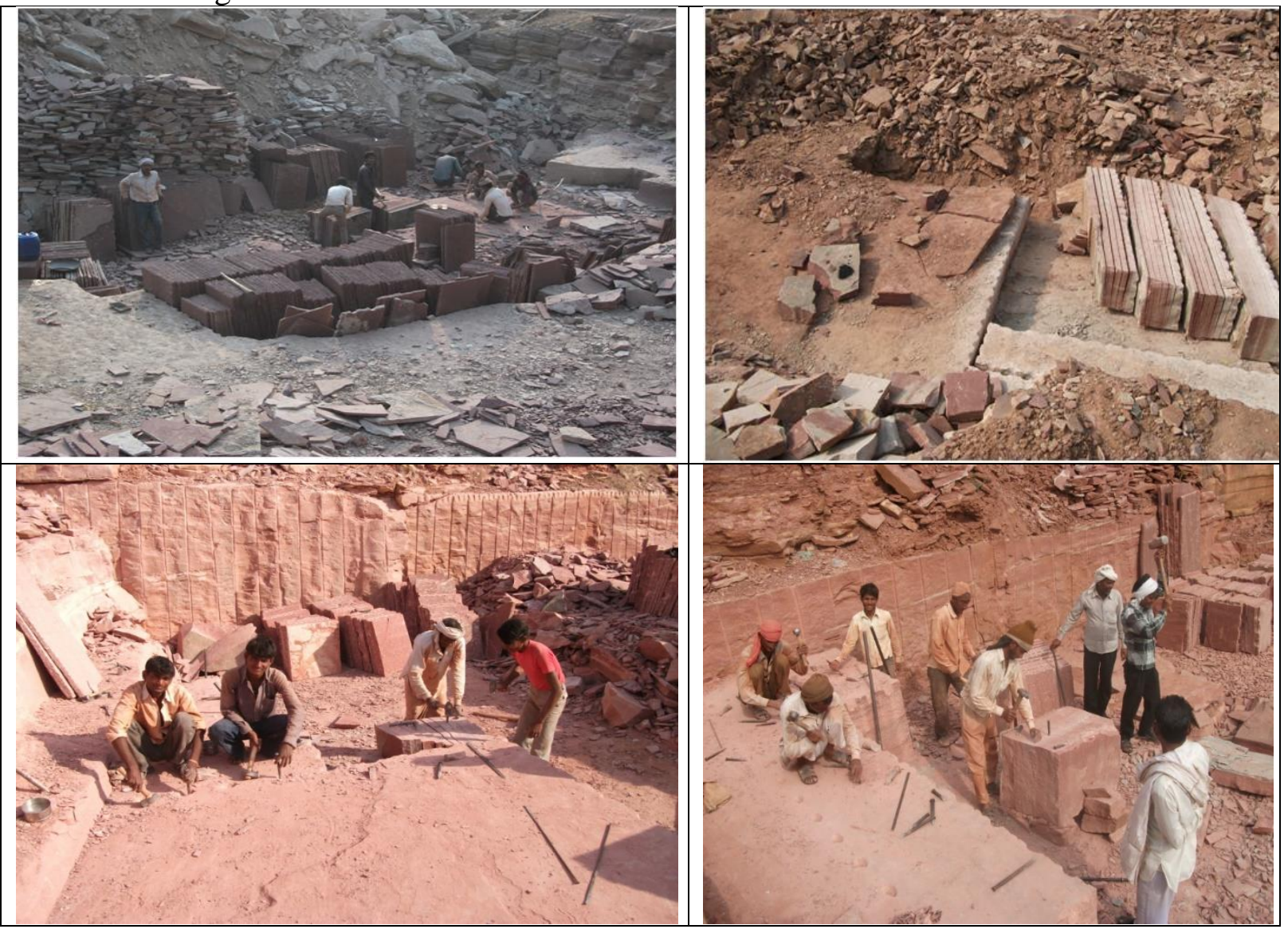

Figure 6: Mining of sandstone in Karauli

Source: Mining pictures from Karauli

Some of the demographic data of the district is shown in the table below;

Table 7: Population Statistics of district Karauli (Age groups and cast wise)

\begin{tabular}{|l|l|c|c|c|c|c|}
\hline SN & \multicolumn{1}{|c|}{ Population } & Persons & Males & $\begin{array}{c}\text { Percentage } \\
(\boldsymbol{\%})\end{array}$ & Females & $\begin{array}{c}\text { Percentage } \\
(\boldsymbol{\%})\end{array}$ \\
\hline 1 & Total & 349,128 & 187,892 & $53.82 \%$ & 161,236 & $46.18 \%$ \\
\hline 2 & $\begin{array}{l}\text { In the age Group 0-6 } \\
\text { years }\end{array}$ & 59,862 & 31,975 & 53.41 & 27,887 & 46.59 \\
\hline 3 & Scheduled Cast & 71,542 & 38,291 & 53.52 & 33,251 & 46.48 \\
\hline 4 & Scheduled Tribe & 55,702 & 30,287 & 54.37 & 25,415 & 45.63 \\
\hline 5 & Literates & $\mathbf{1 8 4 , 0 8 6}$ & $\mathbf{1 2 1 , 1 5 1}$ & $\mathbf{6 5 . 8 2}$ & $\mathbf{6 2 , 9 3 5}$ & $\mathbf{3 4 . 1 8}$ \\
\hline
\end{tabular}

Source: Census 2011 

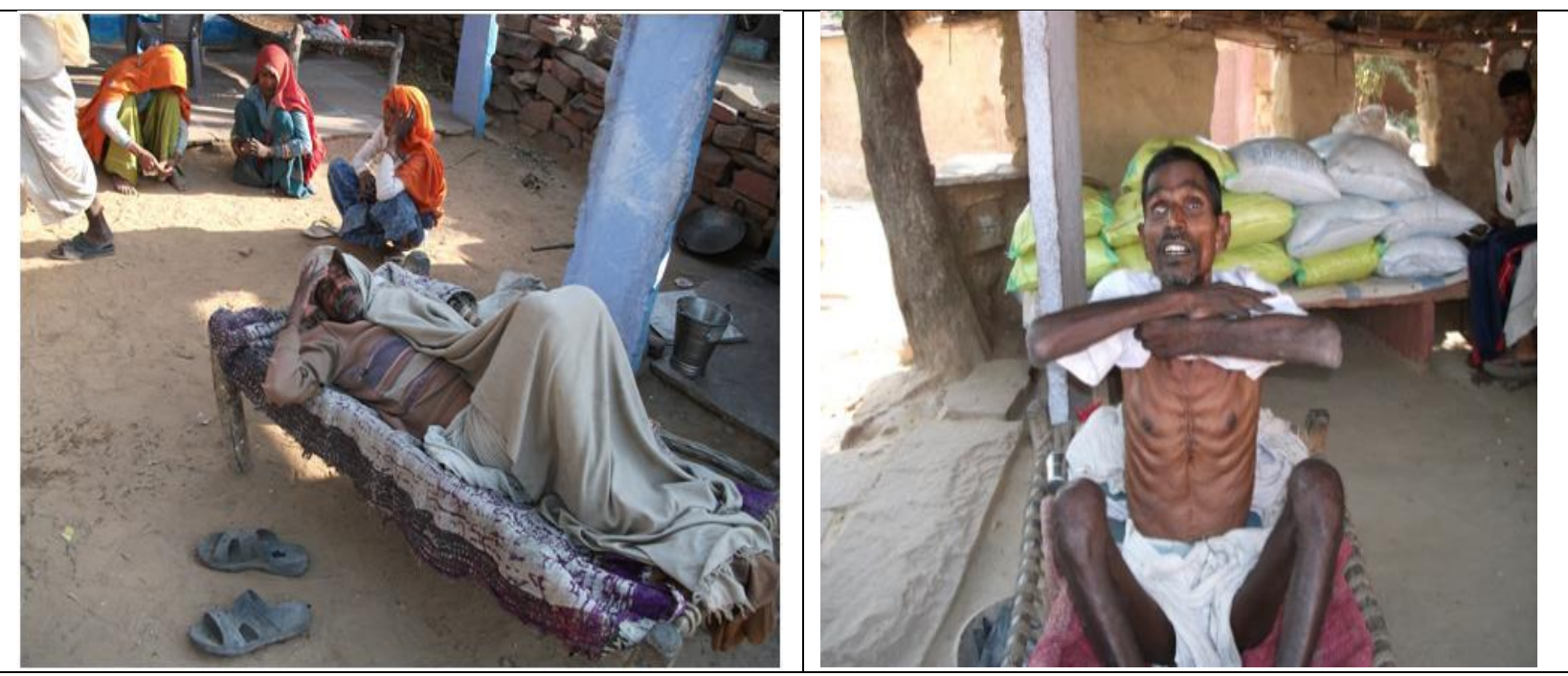

Figure 7: Cases with silicosis from Karauli

\section{Analysis of the Sampled Data}

Data analysis was carried out in the Excel based SGRPQ calculator and the scores obtained were further analyzed by using SPSS software version 17. The total samples had 808 subjects. Out of which around $92.5 \%$ are male, (747) and $7.5 \%$ are female (61) subjects. Majority of the miners are from the SC community (76.73\%) followed by the ST (13.37\%) and OBCs (8.9\%). A negligible percentage $(.99 \%)$ of miners are from the general categories. Disease status of the sampled data; 808 samples drawn from the villages of the district, 312 subjects were confirmed cases of Silicosis; their disease status was confirmed by the PMB, Jaipur, Rajasthan-India established by the Government of Rajasthan. 496 out of 808 subjects had various degrees of respiratory problems probably suspected cases of silicosis since they had years of exposure to silica sand due to their involvement in mining activities.



Figure 8: Demographics of the study data 
Table 7: Village wise distribution of the sampled data

\begin{tabular}{|l|c|c|c|c|}
\hline \multicolumn{1}{|c|}{ Villages } & Frequency & Percent & Valid Percent & Cumulative Percent \\
\hline Arampura-Mahu & 145 & 17.9 & 17.9 & 17.9 \\
\hline Chobe Ki Guwari & 50 & 6.2 & 6.2 & 24.1 \\
\hline Gadi Ka Gaon & 59 & 7.3 & 7.3 & 31.4 \\
\hline Palanpur & 70 & 8.7 & 8.7 & 40.1 \\
\hline Binega & 40 & 5.0 & 5.0 & 45.0 \\
\hline Mamchari & 444 & 55.0 & 55.0 & 100.0 \\
\hline Total & $\mathbf{8 0 8}$ & $\mathbf{1 0 0 . 0}$ & $\mathbf{1 0 0 . 0}$ & \\
\hline
\end{tabular}

Table 8: General prevalence of silicosis

\begin{tabular}{|l|c|c|c|c|c|}
\hline \multicolumn{1}{|c|}{ Villages } & $\begin{array}{c}\text { Confirmed } \\
\text { Cases }\end{array}$ & $\begin{array}{c}\text { Probable } \\
\text { Cases }\end{array}$ & $\begin{array}{c}\text { Total } \\
\text { Cases }\end{array}$ & $\begin{array}{c}\text { Village } \\
\text { Population }\end{array}$ & $\begin{array}{c}\text { Overall } \\
\text { Prevalence }\end{array}$ \\
\hline Arampura-Mahu & 45 & 100 & 145 & 710 & 20.71 \\
\hline Chobe Ki Guwari & 0 & 50 & 50 & 566 & 8.83 \\
\hline Garhi Ka Gaon & 18 & 41 & 59 & 632 & 9.34 \\
\hline Palanpur & 12 & 58 & 70 & 1947 & 3.60 \\
\hline Binega & 0 & 40 & 40 & 1026 & 3.89 \\
\hline Mamchari & 236 & 208 & 444 & 2094 & 21.20 \\
\hline Total & $\mathbf{3 1 1}$ & $\mathbf{4 9 7}$ & $\mathbf{8 0 8}$ & $\mathbf{6 7 7 5}$ & $\mathbf{1 1 . 5 8}$ \\
\hline
\end{tabular}

Table 9: Prevalence of confirmed and suspected cases of silicosis

\begin{tabular}{|l|c|c|c|c|}
\hline \multicolumn{1}{|c|}{ Villages } & Confirmed Cases & Prevalence & Probable Cases & Prevalence \\
\hline Arampura-Mahu & 45 & 6.34 & 100 & 14.08 \\
\hline Chobe Ki Guwari & 0 & 0.0 & 50 & 8.83 \\
\hline Garhi Ka Gaon & 18 & 2.85 & 41 & 6.49 \\
\hline Palanpur & 12 & 0.62 & 58 & 2.98 \\
\hline Binega & 0 & 0.0 & 40 & 3.90 \\
\hline Mamchari & 236 & 11.27 & 208 & 9.93 \\
\hline Total & $\mathbf{3 1 1}$ & $\mathbf{3 . 5 1}$ & $\mathbf{4 9 7}$ & $\mathbf{7 . 7 0}$ \\
\hline
\end{tabular}

Table 10: Adjusted prevalence of confirmed cases of silicosis amongst males

\begin{tabular}{|l|c|c|c|}
\hline \multicolumn{1}{|c|}{ Villages } & $\begin{array}{c}\text { Adjusted Male Population } \\
\text { 6+ Years }\end{array}$ & $\begin{array}{c}\text { Confirmed } \\
\text { Cases }\end{array}$ & $\begin{array}{c}\text { Prevalence } \\
\text { Confirmed Cases }\end{array}$ \\
\hline Arampura-Mahu & 306 & 45 & 14.71 \\
\hline Chobe Ki Guwari & 228 & 0 & 0.00 \\
\hline Garhi Ka Gaon & 280 & 18 & 6.43 \\
\hline Palanpur & 898 & 12 & 1.34 \\
\hline
\end{tabular}




\begin{tabular}{|l|c|c|c|}
\hline Binega & 468 & 0 & 0.00 \\
\hline Mamchari & 879 & 236 & 26.85 \\
\hline Total & $\mathbf{3 0 5 9}$ & $\mathbf{3 1 1}$ & $\mathbf{1 0 . 1 6}$ \\
\hline
\end{tabular}

Table 11: Prevalence of silicosis amongst various casts of the district

\begin{tabular}{|l|c|c|c|c|c|}
\hline Casts & $\begin{array}{c}\text { Total } \\
\text { Cases }\end{array}$ & $\begin{array}{c}\text { Confirmed } \\
\text { Cases }\end{array}$ & $\begin{array}{c}\text { Suspected } \\
\text { Cases }\end{array}$ & $\begin{array}{c}\text { Disease } \\
\text { Prevalence }\end{array}$ & $\begin{array}{c}\text { Prevalence of } \\
\text { probable cases }\end{array}$ \\
\hline SC & 620 & 271 & 349 & 43.71 & 56.29 \\
\hline ST & 108 & 34 & 74 & 31.48 & 68.52 \\
\hline OBC & 72 & 6 & 66 & 8.33 & 8.33 \\
\hline General & 8 & 0 & 8 & 0 & 0.99 \\
\hline Total & $\mathbf{8 0 8}$ & $\mathbf{3 1 1}$ & $\mathbf{4 9 7}$ & $\mathbf{3 8 . 4 9}$ & $\mathbf{6 1 . 5 1}$ \\
\hline
\end{tabular}

Table 12: Prevalence of silicosis amongst smokers and non-smokers

\begin{tabular}{|l|c|c|c|}
\hline Exposure to Smoking & Percentage & Confirmed Cases & $\begin{array}{c}\text { Prevalence of Disease } \\
(\boldsymbol{\%})\end{array}$ \\
\hline Non-Smokers & 217 & 66 & 26.73 \\
\hline Smokers & 591 & 245 & 73.27 \\
\hline Total & $\mathbf{8 0 8}$ & $\mathbf{3 1 1}$ & $\mathbf{1 0 0}$ \\
\hline
\end{tabular}

Table 13: Correlation amongst symptom, activity, and impact scores, smoking and silica exposure (direct/indirect exposure)

\begin{tabular}{|l|c|c|c|c|c|c|}
\hline \multicolumn{1}{|c|}{ Variable } & $\begin{array}{c}\text { Exposure } \\
\text { to Silica } \\
\text { Dust }\end{array}$ & $\begin{array}{c}\text { Symptom } \\
\text { Score }\end{array}$ & $\begin{array}{c}\text { Activity } \\
\text { Score }\end{array}$ & $\begin{array}{c}\text { Impact } \\
\text { Score }\end{array}$ & $\begin{array}{c}\text { Smoking } \\
\text { Exposure }\end{array}$ & $\begin{array}{c}\text { Total } \\
\text { Score }\end{array}$ \\
\hline $\begin{array}{l}\text { Exposure to Silica } \\
\text { Dust }\end{array}$ & 1 & $.281(* *)$ & $.311(* *)$ & $.311(* *)$ & $.205(* *)$ & $.200(* *)$ \\
\hline Symptom Score & $.281(* *)$ & 1 & $.889(* *)$ & $.889(* *)$ & $.126(*)$ & $.817(* *)$ \\
\hline Activity Score & $.311\left(^{* *}\right)$ & $.889\left(^{* *}\right)$ & 1 & $1.000(* *)$ & .113 & $.858(* *)$ \\
\hline Impact Score & $.311\left(^{* *}\right)$ & $.889\left(^{* *}\right)$ & $1.000(* *)$ & 1 & .113 & $.859(* *)$ \\
\hline Smoking Exposure & $.205(* *)$ & $.126(*)$ & .113 & .113 & 1 & .073 \\
\hline Total Score & $.200(* *)$ & $.817(* *)$ & $.858(* *)$ & $.859(* *)$ & .073 & 1 \\
\hline
\end{tabular}

$* *$ Correlation is significant at the 0.01 level (2-tailed).

* Correlation is significant at the 0.05 level (2-tailed).

\section{Results}

In this epidemiological survey of six villages with a population of 6975 revealed that silicosis has emerged as a serious challenge to the district health authorities; >1288 cases have been diagnosed provisionally (till August 2016) in the entire district by the private Occupational Health Specialist located in Jaipur and the District Tuberculosis Officer (DTO) located in Karauli district headquarters. Since the victims of the silicosis have to be compensated, as per the law, it is mandatory that each case have to be certified by the Pneumoconiosis Medical Board (PMB). Out of 1288 cases, 687 cases are before the PMB, Jaipur; they have confirmed 601 cases having Silicosis, and the rest are still waiting for the certification from the Board. However, since 
the establishment of the PMB in Karauli in 2016, (CMO, Karauli, 2016) the number of diagnosed cases have increased multifold. Until February 2017, there were 2758 cases diagnosed and 2267 cases had received compensation from the government.

In 12 villages of Karauli block, there are 1091 cases of Silicosis, however only 509 cases have been certified by the PMB, Jaipur; rest are waiting to be certified by it. In two villages of Mandaryal block; there are 132 people who have been provisionally diagnosed for having Silicosis and 55 cases have been certified for having Silicosis by the PMB, Jaipur and the remaining are waiting to be certified. In three villages of Hindaun block, 65 cases with the Silicosis who have been diagnosed positively; out of which 37 have been confirmed having Silicosis whereas 28 cases are yet to be certified by the PMB, Jaipur. The Village Kotari has the maximum numbers of the silicosis cases followed by Palanpur and Logatpuriyan. State Government has compensated around 632 cases with the Silicosis in the district.

The age range of the sampled population engaged in mining of the sandstone in the district was 30-60 years. Many cases came across to us, which were observed to be minors while gathering data for this study, but none of them were found to be having respiratory problems hence they were excluded from the study. Findings also reveal that the majority of the miners are from the SC community $76.73 \%$ followed by the ST $(13.37 \%)$ and OBCs $(8.9 \%)$. $>93 \%$ of the subjects were males and females were $<4 \%$ who were engaged in direct and indirect mining of sandstone. $>38 \%$ subjects had silicosis (certified from the PMB, Jaipur). Whereas $61 \%$ subjects had severe to mild respiratory difficulties with known history of sandstone mining activities, majority of the subjects having 20-40 years of exposure to silica due to their direct and indirect involvement in mining activities. Further analysis of the revealed that there was no women in the sampled data certified for silicosis.

In the entire six sampled villages, $38.6 \%$ of the subjects had the disease, which was confirmed by the PMB, however $61.4 \%$ of the subjects had various degrees of respiratory symptoms and exposure to silica dust for number of years; making them suspected cases of silicosis. Majority of the subjects ( $>54 \%$ of the cases and suspected cases) were drawn from the village Mamchari, one of the largest villages of the district with a population of 2094 followed by Arampura $>17 \%$ with a population of 710; Palanpur $>8 \%$ with a population of 1947; Gadi Ka Gaon 7\% with a population of 532; Chaube Ki Guwari $6 \%$ with a population of 566 and Binega village with a population of 1026 contributed $5 \%$ cases and suspected cases of silicosis. The leading overall prevalence of the disease (cases and suspected cases) was found to be the highest in Mamchari village amongst the entire six sampled villages (21\%) followed by Arampura (20\%), Chaube Ki Guwari (9\%), Garhi Ka Gaon (6\%), and Binega village (4\%). The overall prevalence of the disease in the entire six sampled villages is found to be around $12 \%$.

Prevalence of Silicosis (confirmed and probable) varies village to village. Arampura village has around $6 \%$ prevalence of Silicosis (confirmed) and 14\% (suspected cases). Mamchari village had $11 \%$ (confirmed) and $10 \%$ (suspected) prevalence of the disease. Chobe Ki Guwari had $0 \%$ (confirmed) and 9\% (suspected) prevalence of silicosis. Garhi Ka Gaon has $2.85 \%$ (confirmed) and $6.49 \%$ (suspected) and Palanpur has prevalence of $0.62 \%$ confirmed and $2.98 \%$ suspected cases whereas prevalence in Binega village of confirmed and suspected cases is .0\% and 3.90\% respectively. The overall prevalence of the disease confirmed and suspected cases amongst all 
the sampled villages is $4 \%$ and $8 \%$ respectively. Adjusted prevalence of confirmed cases of the silicosis amongst the male population (above 6 years) in Mamchari village was found to be around 27\% was found in Mamchari village followed by Arampura 14\%, Gadi Ka Gaon 6\%. Binega and Chobe Ki Guwari villages had $0 \%$ respectively. The overall adjusted prevalence of confirmed cases of silicosis amongst the male above 6 years was found to be $10 \%$. Whereas adjusted prevalence of suspected cases of silicosis amongst males was found to be the highest in Arampura village around 29\% followed by Chaube Ki Guwari 21\%, Mamchari 21\% and Gadi Ka Gaon 13\%. The lowest adjusted prevalence of silicosis disease amongst males was found in Palanpur (5\%) and $7 \%$ in Binega. Overall, $16 \%$ of the male populations amongst the entire six sampled villages were suspected cases of silicosis.

The SC community of the district is the worst hit by the Silicosis; it has the highest prevalence of the disease (confirmed cases) $43.71 \%$ followed by ST community $31.48 \%$. The General community does not had any confirmed case of silicosis in the sampled data. OBC community has $8.33 \%$ prevalence of silicosis. The prevalence of probable cases was the highest amongst the ST $(68.52 \%$ community followed by the SC $(56.29 \%)$ and OBC $(8.33 \%)$ and general community (0.99\%). The average silica exposure due to mining activities in the sampled data was of 23.99 years with a SD of 9.37. Results further show that the prevalence of disease amongst those who were directly exposed to the silica dust is the highest (41.97\%) and those who were indirectly engaged in ancillary mining work particularly women the prevalence of the disease was $0 \%$. The prevalence of the disease amongst the nonsmokers was $26.73 \%$ and with the smokers it was $73.27 \%$.

The scores obtained in normal individuals with no history of respiratory problems in the SGRQ scale, a tool designed to assess the effect of chronic respiratory disease on Health related Quality of Life (HRQoL) in different domains suggest that the activities of the cases and suspected cases of silicosis are disturbed or limited by breathlessness. The ideal activity scores in a normal individual with no history of chronic respiratory problem are (7-12). Whereas in the sampled subjects around $67 \%$ had scores 18.80 which is very close to the normal range, however any 4 points increase above the normal range is clinically important (Monteagudo, et al., 2013). However, around $33 \%$ of the subjects had scores of more than 18.80 , which shows that these subjects had respiratory problems of severe natures, which impacted their physical well-beings. > $7 \%$ of the subjects had 37-38 scores and more than $24 \%$ subjects had scores of 61-62, which is very high signifying serious nature of their respiratory problems.

Symptoms domain assesses frequency and severity of the respiratory symptoms of a case. The scores under this domain in a normal individual without a history of respiratory problems range from (1-3). The minimum score and maximum symptom scores of the subjects were 44 and 100 respectively. The mean score was around $63 \%$ with a SD of 22 . This signifies that the subjects differed in terms of severity and frequency of respiratory symptoms and majority of the subjects suffered from the severe to profound levels of frequency and severity of the respiratory symptoms. Impact Scores indicate how the respiratory problems affects the social functioning and create psychological disturbances in patients having chronic respiratory problems. The scores of the healthy subjects with no histories of respiratory problems scores lies in between (13 ). The average score on this domain was 25.14 with a SD of 5.8. The minimum score is 18.09 and the maximum 35.77. These scores imply that the most of the subjects are facing severe 
nature of social and psychological difficulties in their day-to-day lives. Around $4 \%$ cases had an impact score of 18 . The maximum people around $64 \%$ had a score of 22 and around $23 \%$ people had score of 33 and above.

\section{Discussions}

This epidemiological survey reveals that the Karauli is the worst hit district by the silicosis in the entire Rajasthan. DVS, an NGO working for the rehabilitation of the victims of silicosis reports that in Karauli district $>2500$ cases have been certified with silicosis out of which $>2000$ have received compensation from the Government (Bhardwaj, V., Dr., 2017). There is large number of cases pending to be certified for the diseases due to delay in establishment of the district level PMB. The district level PMB was constituted by the end of 2016 (CMO Karauli, 2016). Majority of the sampled population had 30-60 years of mining sandstone exposure; implying that people enter mining at early age. A study conducted jointly by ARAVALI, Jaipur and Canberra University on sandstone quarry workers of Karauli reports that people enters sandstone quarries due to poverty in young age when they should be in schools and colleges (Dutt, 2015) Sampled population age included sandstone quarry workers from 22 to 75. Minors quarry workers were excluded since none of them reported respiratory difficulties. This may be because silica exposure takes decades to develop the symptoms of the silicosis disease, in case of classic and chronic silicosis (American Thoracic Society, 2013). People are compelled to enter the mining work at early ages because of the deaths of their fathers due to the same profession (Ahemad, 2015).

Findings also reveal that the majority of the miners are from the SC community $76.73 \%$ followed by the ST (13.37\%) and OBCs (8.9\%). Similar finding has been reported that most of the mines workers come from the poorer sections of the society and most of them (95\%) are Dalits and Tribal (MLPC, 2005). >93\% of the subjects were males and females were <4\% who were engaged in direct and indirect mining of sandstone. This is because mining is seen as masculine industry and it is perceived that women play insignificant role in it. They are only around $6.5 \%$ of the total workforce (Ghose, 2008). >38\% subjects had silicosis whereas $61 \%$ subjects had severe to mild respiratory difficulties with known history of sandstone mining activities and they were suspected cases of silicosis. This implies that there is high prevalence of silicosis amongst the miners. A study conducted by the ARAVALI, Jaipur and NIMH, Nagpur reports that the mines workers had $>74 \%$ silicosis (Sishodiya, et al., 2011). Majority of the mines workers had 20-40 years of exposure to silica due to their direct and indirect involvement in mining activities. A study carried out in Karauli district on mines workers revealed that most of the miners have exposure to the silica > two decades (Dutt, 2015). Further analysis of the revealed that there was no women in the sampled data certified for silicosis. This may be due to indirect involvement of women in the mining activities such as in cleaning the bed of the mining, removal of debris. Direct exposure to freshly fractured silica is the most hazardous as they penetrate deep into lungs (OKI, 2008).

There were distinct variations in prevalence of silicosis cases and suspected cases amongst all the six villages; the highest was in the Mamchari village followed by Arampura, Palanpur Gadi Ka Gaon, Chaube Ki Guwari, and Binega village. This implies that the villages where NGO workers were active in Mamchari and Arampura villages on diagnosis and rehabilitation of the silicosis 
victims and that was the reason for high degree of awareness amongst the villagers leading to higher detection of silicosis cases. Dutt, 2015 reports that majority of the workers are illiterate or barely literate. Further, a study reported that degree of awareness about the causation of silicosis is connected with the level of education and acquired knowledge of the workers; it finds that most of the quarry workers delays proper diagnosis and medical aid due to various reasons (Yadav \& Singh, 2011)

The SC community of the district is the worst hit by the Silicosis; followed by the ST and OBC communities. Ahemad, (2015) reported that the people involved in the mining activities in the district Karauli are poor and come from the lower strata of the society such as Jatav, Koli, and Mali. Most of them are from the Scheduled Cast (SC) and Other Backward Communities (OBCs). The prevalence of the disease amongst the nonsmokers was $26.73 \%$ and with the smokers, it was $73.27 \%$. Ahmad, (2015) reported that majority of the workers are addicted to substance abuse. Commonly abused substances are alcohol, and tobacco. Further, findings reveal exposure to silica is significantly correlated with that of exposure to smoking. This implies that smoking tobacco has synergic effect with that of the development of the silicosis disease (Álvarez, et al., 2015).

SGRQ scale \{perfect health (0) to worst possible state of health (100) \} specifically designed to assess the effect of chronic respiratory disease on Health related Quality of Life (HRQoL). Study results reveal that the subjects scored high on activity, symptom, and impact domain suggesting that the activities of the cases and suspected cases of silicosis are disturbed or limited by breathlessness. High symptom scores suggest that the majority of the subjects suffered from the severe to profound levels of frequency and severity of the respiratory symptoms and, high impact scores imply that the most of the subjects are facing severe nature of social and psychological difficulties in their day-to-day lives. On SGRQ scale any 4 points increase above the normal range is clinically important (Monteagudo, et al., 2013).

\section{Conclusions}

Silicosis has emerged as an epidemic in the state of Rajasthan and Karauli is by far the most affected district by silicosis in entire state. This has posed a serious socioeconomic challenge for the state in general and Karauli in specific. People are entering into sandstone quarrying in absence of alternate livelihoods and extreme poverty prevalent in the district. People enter into the trade at very early age to support their families. Working class people from the vulnerable communities (SC, ST, and OBCs) are the worst affected with the disease and if preventive and control measures in war footings not initiated by the Government, the working class manual workers will get wiped out from the district. The disease has affected only the male workers since mining is predominantly masculine work in nature. No minors engaged in the mining were found to be affected by the disease. This was because of the long gestation period of the disease. There is variation of the prevalence from one village to another. It was noted that the area where NGOs were active and were near to the district headquarters reported more number of cases. This is because of the degree of awareness amongst the population about the disease, educational level of the miners and the degree of accessibility and availability to the health and diagnostic facilities. Smokers are the most affected than that of nonsmokers because the smoking has synergic impact on the development of silicosis. The quality life of the of the silicosis victims is 
poor. Victims' activities are seriously disturbed due to breathlessness; exhibit severe to profound levels of respiratory symptoms of the disease; causing social and psychological difficulties to the patients.

\section{Acknowledgement}

Authors are indebted to the contributions and guidance they received from Dr P.K. Shishodiya, former Director, NIMH, Nagpur, Dr Vikas Bhardwaj and his team from DVS, Karauli, and Varun Sharma from ARAVALI, Jaipur

\section{References}

[1] Ahmad, A. (2015). Silicosis, mining, and occupational health in India's sand stone industry. EHS Journal. Retrieved from http://ehsjournal.org/http:/ehsjournal.org/absar-ahmad/silicosis-miningand-occupational-health-in-indias-sandstone-industry/2015/

[2] Ahmad, A. (2015). Are the sandstone miners' abuses in India? INDIAN JOURNAL OF COMMUNITY HEALTH, 27(2), 1-4. Retrieved from file:///C:/Users/smmohammad/Downloads/1001-6345-2-PB.pdf

[3] Ahmad, A. (2015). Land of window. Indian Journal of Community Health, 27(1), Jan-March, 165-166.

[4] Álvarez, R. F., González, C. M., Martínez, A. Q., Fernández, L. C., \& Fernándezc, A. P. (2015). Guidelines for the diagnosis and monitoring of silicosis. Arc Bronconeumol, 51(2), 86-93.

[5] American Thoracic Society. (2013). Occupational Lung Diseases. Retrieved March 18, 2017, from https://www.thoracic.org/patients/patient-resources/breathing-in-america/resources/chapter13-occupational-lung-diseases.pdf

[6] Antão, V. C. d. S., Pinheiro, G. A., Kavakama, J. and Terra-Filho, M. (2004), High prevalence of silicosis among stone carvers in Brazil. Am. J. Ind. Med., 45: 194-201. doi:10.1002/ajim.10331

[7] Bang, K. M., Mazurek, J. M., Wood, J. M., White, G. E., Hendricks, S. A., \& Weston, A. (2015). Silicosis mortality trends and new exposures to respirable crystalline silica - united states, 2001-2010. Morbidity and Mortality Weekly Report ,CDC, 64(5), 117-120. Retrieved from http://search.proquest.com/docview/1658535331/fulltextPDF/7F4BF3744B264CC9PQ/1?account $\mathrm{id}=142908$

[8] Bhardwaj, V., Dr. (2017, March 15). Silicosis cases in Karauli [E-mail]. Secretary, Dang Vikas Sanstha, Karauli

[9] CDC. (2005, February 13). Silicosis Mortality Trends and New Exposures to Respirable Crystalline Silica - United States, 2001-2010. Morbidity and Mortality Weekly Report, 64(05), 117-120.

[10] Chief Medical Officer, Karauli (2016), Exec. Order No. 132. Constitution of Pneumoconiosis Medical Board (PMB)

[11] Cunningham, J. G. (1930). Occurrence Of Silicosis In Canada. Retrieved March 21, 2017, from http://socserv.mcmaster.ca/oldlabourstudies/onlinelearning/article.php?id=49

[12] Dutt, K. L. (2015). Sandstone quarry workers Karauli, Rajasthan, India. Retrieved from http://aravali.org.in/themes/upload/news/351161.pdf

[13] Dugdale, D. C., Hadjiliadis, D., \& Zieve, D. (2016, November 17). Silicosis, health guide. The New York Times. Retrieved from http://www.nytimes.com/health/guides/disease/silicosis/overview.html

[14] Elcosh-Electronic Library, (2016). Silica: The deadly dust. Retrieved from elcosh-Electronic Library of Construction Occupational Safety and Health website: http://www.elcosh.org/document/1426/664/d000803/1.html 
[15] Ferreira, L. R., Pinheiro, T. M, Siqueira, A., L., et al., (2008). Silicosis among semiprecious gem cutters in Joaquim Felício, Minas Gerais State, Brazil. Cadernos de Saúde Pública, 24(7), 15171526. https://dx.doi.org/10.1590/S0102-311X2008000700006

[16] Greenberg, M. I., Waksman, J., \& Curtis, J. (2007). Silicosis: A Review. Disease-a-Month, 53(8), 394-416.

[17] Ghose, M. K. (2008). A Perspective on community and state interests in small -scale mining in India including the role of women. Environment, Development and Sustainability, 10(857). Retrieved from http://link.springer.com/article/10.1007/s10668-007-9088-1

[18] Heaney, P. J., Prewitt, C. T., \& Gibbs, G. V. (1994). Silica: Physical behavior, geochemistry, and materials applications. In Review in minerology. New Jersey, USA: Princeton. Retrieved from http://www.minsocam.org/msa/rim/rim29.html

[19] Human Development Report Rajasthan- an update (2008). Retrieved from Relative Human Development Index in Rajasthan website: http://www.im4change.org/docs/569hd_final.pdf

[20] How Med, (2015). Pneumoconiosis -types, silicosis, asbestosis and preventive measures. Retrieved from How Med website: http://howmed.net/community-medicine/pneumoconiosistypes-silicosis-asbestosis-and-preventive-measures/

[21] International Agency for Research on Cancer (1997) IARC monographs on the evaluation of carcinogenic risks to humans, silica, some silicates, coal dust and para-aramide fibrils, p 68

[22] ILO (2011). Specific instructions for use of the complete classification. In Guidelines for the use of the international classification of radiographs of pneumoconiosis (pp. 3-9). Geneva: ILO. Retrieved from http://www.ilo.org/wcmsp5/groups/public/---ed_protect/---protrav/--safework/documents/publication/wcms_168260.pdf

[23] ICMR Bulletin. (1999, September). Silicosis - An Uncommonly Diagnosed Common Occupational Disease. Retrieved April 1, 2017, from http://icmr.nic.in/busep99.htm

[24] Jeffery, S. J., Dirk, E., Craig, S. C., \& Kevin, B. K. (2014). The psychometric properties of the St George's Respiratory Questionnaire (SGRQ) in patients with idiopathic pulmonary fibrosis: A literature review. Health and Quality of Life Outcomes Health Qual Life Outcomes, 12(124). Retrieved March 12, 2016, from http://www.ncbi.nlm.nih.gov/pmc/articles/PMC4148554/

[25] Kachuri, L., Villeneuve, P. J., Parent, M.-É., Johnson, K. C., Harris, S. A. (2014), Occupational exposure to crystalline silica and the risk of lung cancer in Canadian men. Int. J. Cancer, 135: 138-148. doi:10.1002/ijc.28629

[26] Leung, C. C., Sun Yu, I. T., \& Chen, W. (2012).Silicosis. The Lancet, 379(9830), 2008-2018. Retrieved from http://www.thelancet.com/journals/lancet/article/PIIS0140-6736(12)602359/fulltext?version\%3DprinterFriendly

[27] Luton, T. (2007). Silicosis- Educate, Eliminate, Eradicate. Australian Tile Publication, 12, 32-38. Retrieved Feb. \& march, 2017, from http://www.indianet.nl/pdf/silicosis.pdf

[28] MLPC, (2005). 'Organizing the unorganized'. Retrieved from Mine Labor Protection Campaign (MLPC) website:

http://www.asmasiapacific.org/wpcontent/uploads/2014/07/BaharDutt2005_OrganisingTheUno.pdf

[29] Madl, A. K., Donovan, E. P., Gaffney, S. H., McKinley, M. A., Moody, E. C., Henshaw, J. L., \& Paustenbach, D. J. (2008). State-of-the-science review of the occupational health hazards of crystalline silica in abrasive blasting operations and related requirements for respiratory protection. Journal of Toxicology and Environmental Health, Part B (11), 548-608. Retrieved fromhttps://faculty.unlv.edu/buckb/scanned\%20pfd/Madl\%20et\%20al\%202008.pdf

[30] Marble Institute of America, (2008). History of silicosis. In Silicosis, an industry guide to awareness and prevention (p. 3). Ohio: MIA. Retrieved from http://www.marbleinstitute.com/default/assets/File/news/Silicosis_Industry_Guide_Tech_Module_2008.pdf 
[31] Monteagudo, M., Rodriguez-Blanco, T., Llagostera, M., Valero, C., Bayona, X., Ferrer, M. \& Miravitlles, M. (2013). Factors associated with change in quality of life of COPD patients: A prospective study in primary care. Respiratory Medicine, 107, 1589-1597.

[32] NIMH. (2012, February 21). Notified Diseases in Mines. Retrieved May 15, 2017, from http://www.nimh.gov.in/downloads/WorkshopNIMH2012.pdf

[33] NIOH \& Pan American Health Organization. (2009, October). AMERICAS ELIMINATION OF SILICOSIS INITIATIVE. Retrieved March 18, 2017, from http://new.paho.org/hq/dmdocuments/2009/Silicosis\%20Fact\%20Sheet\%20FINAL.pdf

[34] OKI. (2008). Guidance for Controlling Silica Dust from Stone Crushing with Water Spray Technology. Retrieved April 17, 2017, from

http://www.okinternational.org/docs/Guidance\%20for\%20Controlling\%20Silica\%20Dust\%20fro $\mathrm{m} \% 20$ Stone $\% 20$ Crushing\%20with\%20Water\%20Spray\%20Technology\%20$\% 20$ for\%20Employers.pdf

[35] Paap, M. S., Brouwer, D., Glas, C. W., Monninkhof, E. M., Forstreuter, B., Pieterse, M. E., \& Palen, J. D. (2013). The St George's Respiratory questionnaire revisited; A psychometric evaluation. Quality of Life Research, 24, 64-79. doi:10.1007/s11136-013-0570-y

[36] Sishodiya, P. K., Nandi, S. S., \& Dhatarak, S. V. (2011).Detection of silicosis among stone mine workers from Karauli district February national institute of miners' health (ministry of mines, govt. of India) jnarddc campus, Amravati Road, Wadi, Nagpur report - ii. Nagpur: National Institute of Miners' Health, Government of India.

[37] Steenland, K. and Ward, E. (2014), Silica: A lung carcinogen. CA A Cancer Journal for Clinicians, 64: 63-69. doi:10.3322/caac.21214

[38] Shishodiya, P. K., Nandi, S. S., \& Dhatrak, S. V. (2014). Detection of silicosis among stone mine workers from Karauli district, National Institute of Miners' Health (Ministry of Mines, Govt. of India) jnarddc campus, Amravati road, Wadi, Nagpur report - ii. Nagpur: National Institute of Miners' Health, Government of India.

[39] Shishodiya, P. K., Dr. (2017, March 15). Silicosis Status of Rajasthan [E-mail to the author]. Department of Health, Government of Rajasthan

[40] Thomas, C. R., \& Kelley, T. R. (2010). A Brief Review of Silicosis in the United States. Environmental Health Insights, 4, 21-26

[41] Ulm, K., Gerein, P., Eigenthaler, J., \& Schmidt, S. H. (2004). Silica, silicosis and lung-cancer: Results from a cohort study in the stone and quarry industry. Int Arch Occup Environ Health, 77, 313-318.

[42] WHO, (2007). Elimination of silicosis. The Global Occupational Health Network, (12), 1-18. Retrieved fromhttp://www.who.int/occupational_health/publications/newsletter/gohnet12e.pdf

[43] Yadav, S. P., \& Singh, H. (2011). Awareness and Practices about Silicosis among the Sandstone Quarry Workers in Desert Ecology of Jodhpur, Rajasthan, India. J Hum Ecol, 33(3), 191-196. Retrieved April 18, 2017, from file:///C:/Users/smmohammad/Downloads/Awareness_and_Practices_about_Silicosis_among_the _.pdf.

*Corresponding author.

E-mail address: shamim_ifff@yahoo.co.in 